\title{
3 Research Soure \\ Chemical Hybridization of Sulfasalazine and Dihydroartemisinin Promotes Brain Tumor Cell Death
}

\section{Annemarie Ackermann}

University of Erlangen-Nuremberg

Aysun Çapcı

University of Erlangen-Nuremberg

Michael Buchfelder

University of Erlangen-Nuremberg

Svetlana Tsogoeva ( $\nabla$ svetlana.tsogoeva@fau.de)

Organic Chemistry Chair I and Interdisciplinary Center for Molecular Materials (ICMM), FriedrichAlexander University of Erlangen-Nürnberg, Nikolaus Fiebiger-Straße 10, 91058 Erlangen, Germany

Nicolai Savaskan

University of Erlangen-Nuremberg

\section{Research Article}

Keywords: artemisinin, dihydroartemisinin, sulfasalazine, hybrid, glioma, cancer cytotoxicity

Posted Date: January 27th, 2021

DOI: https://doi.org/10.21203/rs.3.rs-126953/v1

License: (c) (i) This work is licensed under a Creative Commons Attribution 4.0 International License. Read Full License 


\section{Abstract}

Gliomas are primary brain tumors with still poor prognosis for the patients despite a combination of cytoreduction via surgery followed by a radio-chemotherapy. One strategy to find effective treatment is to combine two different compounds to add or at best potentiate their impact on malignant cells. Here, we report on the effects of a newly synthesized covalently bound hybrid of sulfasalazine (SAS) and dihydroartemisinin (DHA) called AC254. In previous studies both SAS and DHA have already proved to have anti-tumor properties themselves and to have sensitizing respectively potentiating effects on other treatments against malignant tumors. We investigated the impact of sole SAS and DHA, their 1:1 combination and as a chemical linked hybrid (AC254) on rodent and human glioma cells. In our study SAS showed no or only a mild effect on glioma whereas DHA led to a significant reduction of cell viability in a dose-dependent manner. Next we compared the efficacy of the hybrid AC254 to the combinational treatment of its parent compounds SAS and DHA. The hybrid was highly efficient in combating glioma cells compared to single treatment strategies regarding cell viability and cell death. Interestingly, AC254 showed a remarkable advantage over the combinatorial treatment of both parent substances in most used concentrations. In addition to its reduction in cell viability and induction of cell death the hybrid AC254 displayed changes in cell cycle and reduction of cell migration. Taken together, these results demonstrate that clinically established compounds as SAS and DHA can be potentiated in their anticancer effects by chemical hybridization. Thus, this concept provides the opportunity to provide new chemotherapeutic drugs.

\section{Introduction}

Primary malignant brain tumors (gliomas) are one of the deadliest neoplasia, which carry poor prognosis for patients despite current aggressive multimodal therapies ${ }^{1-3}$. Human gliomas are highly vascularized ${ }^{4}$ and grow in a space-occupying manner. A promising novel approach for generating potent anti-cancer drugs is the hybridization of two or more bioactive compounds with synergistic efficacy profile. In principle this approach combines two or more compounds or fragments and links them with each other via covalent bonds leading to hybrid molecules ${ }^{5-8}$. Generating synthetic hybrids with structures of natural compounds are highly efficient and can be superior to their parent compound ${ }^{9-11}$. As an example, the artesunic acid-marmycin A hybrid has been reported to be superior to artesunic acid and marmycin $A$ against human osteosarcoma U2OS cells having $\mathrm{IC}_{50}$ values $0.23 \mu \mathrm{M}, 1.1 \mu \mathrm{M}$, and $14 \mu \mathrm{M}$, respectively ${ }^{12}$.

In this study we focused on the concept of hybridization, encouraged also by our previous results and experiences with artemisinin-based hybrids ${ }^{13-16,11,17,18}$. Artemisinin is a natural anti-malarial compound which was extracted from the Chinese medicinal plant Artemisia annua $\mathrm{L}$. The unique structure of artemisinin was elucidated by Youyou Tu in 1972 and her discoveries, concerning a novel therapy against malaria, were awarded by Nobel Prize in Physiology or Medicine in $2015^{19}$. 
There are some artemisinin-derived agents with anti-tumoral properties such as artesunic acid which was found to induce cell death in several types of cancer cells such as pancreatic cancer, T leukemia cells, breast cancer cells and myeloid leukemia cells ${ }^{20-23}$. In this study we focused on the artemisinin derivate dihydroartemisinin (DHA) which is in clinical use as an anti-malarial drug ${ }^{24}$. In the past DHA was already found to hold anti-cancer activity in various types of cancer such as colorectal cancer ${ }^{25}$, lung carcinoma ${ }^{26}$, ovarian cancer ${ }^{27}$, leukemia ${ }^{28,29}$, osteosarcoma ${ }^{30}$, prostate cancer ${ }^{31}$, hepatocellular cancer ${ }^{32}$ and pancreatic cancer ${ }^{33}$ with only mild toxicity toward normal healthy cells ${ }^{27,31}$. The mechanism of its properties consist partly of the induction of apoptosis ${ }^{26,27,29,30,33,31,32}$, cell cycle arrest ${ }^{26,33,32}$, antiangiogenetic effects ${ }^{34-36}$ and reduction of migration ${ }^{30}$. In the past DHA has also shown to potentiate the effect of other chemotherapeutic drugs after combining the treatment ${ }^{26,27}$.In search for a substance to combine the artemisinin derivate DHA with we decided on the anti-inflammatory drug sulfasalazine. Sulfasalazine (SAS) has been developed decades ago as an anti-inflammatory drug and is currently in clinical use for the treatment of chronic inflammatory diseases such as rheumatoid arthritis and ulcerative colitis ${ }^{37,38}$. In various experimental studies SAS has already shown anti-tumoral effects on gliomas $^{39-43}$ and other malignant entities such as lymphoma and pancreatic cancer ${ }^{44,45}$. It is especially effective when combining SAS treatment with an established therapy like radiotherapy ${ }^{46,43}$ or chemotherapy ${ }^{47-50}$ in terms of sensitizing malignant cells to treatment and potentiate its effects. Noteworthy, SAS is a pleiotropic drug with various actions including for example induction of cell death ${ }^{51,42}$, inhibition of activation of transcription factor $\mathrm{NFKB}^{52,42,45,50}$ and inhibition of the glutamate antiporter $x \mathrm{CT}^{44,45,53,41}$. In particular, the last named mechanism is hypothesized for the anti-cancer action of SAS especially regarding gliomas ${ }^{41,45}$. Futhermore, it shows peritumeral anti-epileptic activity ${ }^{54}$ and is effective in alleviating tumor-induced brain swelling ${ }^{39}$ which are likewise important characteristics for the treatment of brain tumors. Here, we covalently bound sulfasalazine and dihydroartesiminin thereby generating the compound termed AC254 (Fig. 1). We applied AC254 on glioma cells and AC254 revealed a highly efficient chemotherapeutic effect on gliomas.

\section{Materials And Methods}

\section{Chemicals and General Information ${ }^{11}$}

Dihydroartemisinin (> 98\% (HPLC)) was purchased from TCl Deutschland $\mathrm{GmbH}$, and sulfasalazine (> 98\% (HPLC)) was purchased from Sigma Aldrich, Germany. Thin layer chromatography (TLC) was performed on pre-coated aluminum sheets ALUGRAM® SIL G/UV254 $(0.2 \mathrm{~mm}$ silica gel with fluorescent indicator, MachereyNagel \& Co). NMR spectra were recorded at room temperature on a Bruker Avance spectrometer operating at $300 \mathrm{MHz}$. All chemical shifts are given in the ppm-scale and refer to the nondeuterized proportion of the solvent. ESI mass spectrum was recorded on a Bruker Daltonik micrOTOF II focus TOF MS-spectrometer. Elemental Analysis $(\mathrm{C}, \mathrm{H}, \mathrm{N})$, carried out with an Elementar vario MICRO cube machine, is within $\pm 0.40 \%$ of the calculated values confirming a purity of $>95 \%$. 


\section{Synthesis and characterization of novel hybrid AC254}

In a flame-dried flask, sulfasalazine (100 mg, $0.251 \mathrm{mmol}, 1.0$ equiv.) and dihydroartemisinin (78.51 mg, $0.276 \mathrm{mmol}, 1.1$ equiv.) were dissolved in acetonitrile and the solution was cooled down to $0{ }^{\circ} \mathrm{C}$, under nitrogen atmosphere. The coupling reagents DCC (52 mg, $0.251 \mathrm{mmol}, 1.0$ equiv.) and DMAP (30.66 mg, $0.251 \mathrm{mmol}, 1.0$ equiv.) were added, respectively. The reaction mixture was warmed up to room temperature in 2 hours, following, it was heated up to $40^{\circ} \mathrm{C}$ for an additional 6 hours. The solvent was removed under reduced pressure and the crude mixture was purified via column chromatography using the solvent mixture hexane and ethylacetate in the ratio 6 to $4, R_{f}: 0.24$. The pure compound was obtained as yellow powder with $21 \%$ yield (ratio $\mathrm{C} 10 \beta / \mathrm{C} 10 \mathrm{a}=75: 25) .{ }^{1} \mathrm{H} \mathrm{NMR}\left(300 \mathrm{MHz}, \mathrm{CDCl}_{3}\right) \delta=8.36(\mathrm{~d}, J=2.5$ $\mathrm{Hz}, 1 \mathrm{H}), 8.34(\mathrm{~d}, J=7.1 \mathrm{~Hz}, 1 \mathrm{H}), 8.15(\mathrm{dd}, J=9.0,2.4 \mathrm{~Hz}, 1 \mathrm{H}), 8.10(\mathrm{dd}, J=53.7 \mathrm{~Hz}, 4 \mathrm{H}), 7.73(\mathrm{~m}, 1 \mathrm{H}), 7.43$ $(\mathrm{d}, J=8.8 \mathrm{~Hz}, 1 \mathrm{H}), 7.16(\mathrm{~d}, J=8.9 \mathrm{~Hz}, 1 \mathrm{H}), 6.85(\mathrm{t}, 1 \mathrm{H}), 6.54(\mathrm{~d}, J=3.3 \mathrm{~Hz}, 1 \mathrm{H}), 5.60(\mathrm{~s}, 1 \mathrm{H}), 3.03(\mathrm{~m}, 1 \mathrm{H})$, $2.46(\mathrm{~m}, 1 \mathrm{H}), 2.12(\mathrm{~m}, 2 \mathrm{H}), 1.97(\mathrm{~m}, 3 \mathrm{H}), 1.87(\mathrm{~m}, 2 \mathrm{H}), 1.73(\mathrm{~m}, 2 \mathrm{H}), 1.44(\mathrm{~s}, 3 \mathrm{H}), 1.38(\mathrm{~m}, 2 \mathrm{H}), 1.12(\mathrm{~m}, 2 \mathrm{H})$,

$1.02(\mathrm{~d}, J=2.4 \mathrm{~Hz}, 3 \mathrm{H}), 1.00(\mathrm{~d}, J=3.6 \mathrm{~Hz}, 3 \mathrm{H}) \mathrm{ppm} .{ }^{13} \mathrm{C} \mathrm{NMR}\left(125 \mathrm{MHz}, \mathrm{CDCl}_{3}\right) \delta=164.69,128.03$, $123.17,104.24,96.56,94.76,91.34,87.92,81.26,80.49,52.86,52.66,51.70,45.60,44.48,37.63,37.52$, $36.52,36.44,34.91,34.86,30.94,26.22,26.13,24.86,24.82,24.72,22.28,20.51,20.39,16.32,13.33$, 12.85. ppm. HRMS (ESI+) $\mathrm{m} / z$ calculated for $\mathrm{C}_{33} \mathrm{H}_{35} \mathrm{~N}_{4} \mathrm{O}_{9} \mathrm{~S}[\mathrm{M}+\mathrm{H}]^{+}: 663.2137$; found: 633.2130 . Purity of AC254 was confirmed using elemental analysis, calculated for $\mathrm{C}_{33} \mathrm{H}_{36} \mathrm{~N}_{4} \mathrm{O}_{9} \mathrm{~S}$ : C: $59.63 \mathrm{H}: 5.46 \mathrm{~N}: 8.43$; Found: C: $59.58 \mathrm{H}: 5.40 \mathrm{~N}: 8.89$.

\section{Cell culture glial cell lines}

Rodent (F98) and human (U87) cell lines were obtained from ATCC/LGC-2397 (Wesel, Germany). TN22 cells were generated from surgical resection of glioblastoma multiforme patients after informed consent. Primary surgery was guided with with a Siemens Magnetom 1.5 Tesla intraoperative MRI scanner with integrated BrainLab VectorVision neuronavigation. Dissected tumor was classified according to the functional grading according to Friedlein grading: FG A - located in non-eloquent brain areas, FG B located in the vicinity or in an eloquent brain area ${ }^{55}$. Tissue sample was classified according to the WHO classification of tumor of the CNS. Histopathology was performed by an experienced neuropathologist. TN22 cells were a subclone derived from one female Caucasian patient age 42. TN22 were propagated in Dulbecco's Modified Eagle Medium (DMEM; Biochrom, Berlin, Germany) supplemented with $10 \%$ fetale bovine serum (Biochrom, Berlin, Germany), 1\% Penicillin/Streptomycin (Biochrom, Berlin, Germany) and $1 \%$ Glutamax (Gibco/Invitrogen, California, USA) cultured under standard humidified conditions $\left(37^{\circ} \mathrm{C}, 5 \%\right.$ $\mathrm{CO}_{2}$ ).From Passage 10 on every 10 passage was freezed and stored at liquid nitrogen over passage 100 .

All glioma cells were cultivated in Dulbecco's Modified Eagle Medium (DMEM; Biochrom, Berlin, Germany) modified with $10 \%$ fetale bovine serum (Biochrom, Berlin, Germany), 1 \% Penicillin/Streptomycin (Biochrom, Berlin, Germany) and $1 \%$ Glutamax (Gibco/Invitrogen, California, USA) under standard humidified conditions $\left(37^{\circ} \mathrm{C}, 5 \% \mathrm{CO} 2\right)$. After reaching a confluence of approximate $80-90 \%$ cells were 
passaged. For passaging cells were first washed with PBS, then trypsinized, centrifuged (900xT, 5 min, $24^{\circ} \mathrm{C}$ ) and plated into prepared culture flasks.

\section{Cell culture primary neurons and astrocytes}

Hippocampal neuronal cultures were preserved from the brain of one to four days old Wistar rats (Charles River, USA) by removing the hippocampi from the brain and transferring them into ice cold Hank's salt solution. After cutting away the dentate gyrus the brain tissue was first trypsinized $(5 \mathrm{mg} / \mathrm{ml})$, then triturated mechanically and cultured with MEM medium supplemented with $10 \%$ fetale calf serum and $2 \%$ B27 Supplement (all from Invitrogen, Taufkirchen). After a short span of time the primary neurons and astrocytes were cultivated in Neurobasal A (Invitrogen, Taufkirchen).

\section{Cell viability analysis}

The cell viability assay was performed using 3(4,5 dimethylthiazol) $-2,5$ diphenyltetra-zolium (MTT) assay. 3.000 cells/well were plated into 96-well-plate and treated after 2 hours. After 72 hours MTT solution (Roth, Karlsruhe, Germany) $(5 \mathrm{mg} / \mathrm{ml}$ ) was added and cells were incubated for 4 hours. Then MTT solution was sucked away and cells were lysed with $100 \mu \mathrm{l}$ isopropanol $+\mathrm{HCl}(110 \mathrm{ml}$ Isopropanol + $330 \mu \mathrm{HCl}$ ) for 30 minutes. This described setting was used for the glioma cells F98, U87 and TN22.

Primary neurons and astrocytes were plated into 12-well plates. After $72 \mathrm{~h}$ of treatment cells were incubates with MTT solution as described earlier. After $4 \mathrm{~h}$ of incubation $200 \mu \mathrm{l}$ isopropanol $+\mathrm{HCL}$ was used for cell lysis. $90 \mu \mathrm{l}$ of this solution was transferred into 96 -well plate for measuring with the microplate reader. The optical density of each well was measured using the microplate readaer Tecan Infinite F50 (Crailsheim, Germany) set to $550 \mathrm{~nm}$ using i-control software. The viability of the different treatments is expressed as the percentage of cells without any treatment.

\section{Cell death assay and apoptosis analysis}

Cells were seeded the same way as for the cell viability assay. After 72 hours of treatment cells were stained with propidium iodide staining (PI) (Invitrogen, Darmstadt, Germany) for 20 minutes $[1 \mu \mathrm{g} / \mathrm{ml}]$. Pictures were taken with Olympus x71 and cell-F-Software (Olympus, Tokyo, Japan). The area of fluorescent cells was measured with Image $\mathrm{J}$ software.

Further 100,000 or 200,000 cells/well were plated into 6-well-plates and again treated after $2 \mathrm{~h}$ with $1 \mu \mathrm{M}$. After 24 or $72 \mathrm{~h}$ medium and cells were collected, washed with PBS and stained with 0,1\% Annexin $V$ and 0,1\% 7-ADD (Biolegend, San Diego, USA). Results were obtained by Flow Cytometer BD FACSCanto II (BD Bioscience, Heidelberg, Germany) and analyzed with WinList 3D 8.0 software.

\section{Phalloidin staining procedure}

For the staining of cytoskeleton 50,000 cells were seeded/well on glass cover slides in a 12-well plate. Treatment followed after 5 hours. $24 \mathrm{~h}$ after treatment cells were fixated with PFA $4 \%$ and stained with Phalloidin 488 (1:50) and Hoechst (1:10 000). Pictures were taken by Axio Observer with Zen Software (Zeiss, Oberkochen, Germany). 


\section{Cell migration assay}

100,000 cells/well were plated into 12-well plate. A sratch was made with a sterile pipette tip right through the layer of cells. Images were taken ( $0 \mathrm{~h})$ and cells were treated with different concentrations $(0,5 \mu \mathrm{M}$ and $5 \mu \mathrm{M}$ ) of the compounds. Pictures were taken by Olympus x71 and cell-F-Software (Olympus, Tokyo, Japan) at various times. To analyze the data the distance between cells was measured using Image $\mathrm{J}$ software.

\section{Cell cycle analysis}

For cell cycle analysis 100,000 cells/well respectively 200,000 cells were seeded in 6 -well dishes. After $2 \mathrm{~h}$ cells were treated with $1 \mu \mathrm{M}$ of the different compounds and their combination. After $24 \mathrm{~h}$ respectively $72 \mathrm{~h}$ cells and the media supernatant were collected and washed with PBS. Then cells were fixated with cold $70 \%$ ethanol for 30 minutes at $4{ }^{\circ} \mathrm{C}$. After another wash step with PBS RNAse A $(100 \mu \mathrm{g} / \mathrm{ml})$ and 7AAD solved in PBS were added to the cells for 30 minutes at room temperature. Cell cycle analyses were performed by Flow Cytometer BD FACSCanto II (BD Bioscience, Heidelberg, Germany). Analysis were made with Flowing Software 2 and WinList 3D 8.0.

\section{Hoechst Assay}

100,000 cells/well were plated into 6-well-plates, after $2 \mathrm{~h}$ cells were treated. After $72 \mathrm{~h}$ of treatment medium was removed and cells washed with PBS. Cells were trypzinized and pooled with the removed medium. Cells were again washed with PBS and fixated with 4\% PFA for 10 minutes. After another wash step cells were incubated with Hoechst $(2 \mu \mathrm{g} / \mathrm{ml})$ for 30 minutes. Then cells were moved to microscope slide. Pictures were taken with 40 times enlargement by an Axio Observer with the Zen Software (Zeiss, Oberkochen, Germany).

\section{Three dimensional spheroid migration assay}

For this assay 50,000 cells were plated in $100 \mu$ l of solution (35\% methylcellulose solution and $65 \%$ culture medium DMEM) as a drop on petri dishes and reversely cultured under standard humidified conditions. After $24 \mathrm{~h}$ the spheroid was carfully washed with PBS and transferred into 48-well-plates with $200 \mu \mathrm{l}$ including the different treatment. The size of the spheroid was monitored after $24 \mathrm{~h}, 48 \mathrm{~h}, 72 \mathrm{~h}$ and $96 \mathrm{~h}$ with Olympus x71 and cell-F-Software (Olympus, Tokyo, Japan). The distance between cell package at time $0 \mathrm{~h}$ and the respective time was measured by Image $\mathrm{J}$ software.

\section{Statistical analysis}

Quantitative data from experiments were obtained as stated in the figure legend. Analysis was performed using unpaired Student's $t$ test if not otherwise stated (MS Excel). Data from all experiments were obtained from at least three independent experiments. The level of significance was set at $*=p<0.05$. Error bars represent \pm SEM.

\section{Results}




\section{The SAS hybrids AC254 impact on cell morphology}

The first step was to examine the effect of the parent substances SAS and DHA, their combination and the hybrid on glioma cell morphology using different concentrations. The examination took place after $72 \mathrm{~h}$ of treatment (Figure 2).

The confluence of glioma cells treated with SAS was similar to the confluence visible in the control even when using higher concentrations (Fig. 2 A). However glioma cells treated with DHA behaved differently. In low concentrations there was no effect visible $(0,5 \mu \mathrm{M}, 1 \mu \mathrm{M})$ (Fig. $2 \mathrm{~A})$. The cells looked equal to the control in shape and confluence. Whereas using DHA in higher concentration an increasing impact on cell morphology was visible. There were less cells per area, the cells had less branches and some of them even had a round cell body $(5 \mu \mathrm{M}, 10 \mu \mathrm{M}, 20 \mu \mathrm{M})$ (Fig. 2 A). When treating gliomas with a 1:1 mixture of SAS and DHA they respond similar to cells treated with sole DHA (Fig. 2 A). In low concentration cells did not seem to react to the treatment, only when increasing the concentration the cells changed their appearance. Interestingly using light microscopy detected a considerable difference between cells treated with the hybrid AC254 and cells under controlled conditions already in low concentrations $(0,5 \mu \mathrm{M})$. The cells retracted their membrane extensions, rounded up and had no polygonal shape at all. This effect was displayed in all used concentrations in the same extent (Fig. 2 A). To further investigate the morphological change we had a closer look on the glioma cytoskeleton. Therefore cells were imaged for actin filaments and DNA after $24 \mathrm{~h}$ of treatment with 0,5 $\mu \mathrm{M}$ (Fig. 2 B). We found that both SAS and DHA did not alter significantly cortical and cytoskeletal actin polymerization (Fig. 2 B). The same was true for the SAS and DHA mixture in equal parts. In contrast, the hybrid compound AC254 led to massive actin polymerization in the cytoskeleton (Fig. 2 B).

Summarized these findings indicate that the hybrid AC254 is most effective in changing the shape of glioma cells and reducing cell metabolism compared to the single treatment of its mother substances SAS and DHA and there 1:1 combination. Furthermore it shows that linking molecules together can create a new compound with new properties.

\section{The impact of AC254 compared to its parent compounds on cell viability.}

Next we examined the impact of SAS, DHA, their combination and the covalent bound hybrid of SAS and DHA on rodent glioma cells. Hence, the F98 glioma cells were treated with various concentrations of sole SAS, sole DHA, their 1:1 mixture and the hybrid termed AC254. We investigated with this approach the impact of SAS and its hybrid molecule on primary brain tumors, in particular gliomas (Figure 3).

For this we analyzed the consequences of the treatment with a wide range of concentrations on cell viability after $72 \mathrm{~h}$ of treatment. First looking at the parent compounds our experiments showed no or rather a slight difference when treating cells with SAS compared to control (Fig. 3 A, C). These results confirm previous studies with SAS on glioma cells which found an affective concentration of SAS for reducing cell viability at $200 \mu \mathrm{M}^{39}$. The other parent substance DHA however decreased cell viability already significant in a low concentration $(0,5 \mu \mathrm{M})$ (Fig. 3 A, D). This effect is increasing in a dose- 
dependent manner. At the highest concentration we used $(20 \mu \mathrm{M})$ in our study glioma cell viability was reduced to a level of approximately $30 \%$ when treating with DHA (Fig. 3 D).

To exclude the possibility that the solvent DMSO used for solving the compounds had any effects on our results. We performed the cell viability assay and the microscopy also with the highest concentration of DMSO $(0,05 \%)$. We used this concentration only for the combinatorial treatment of SAS and DHA at 20 $\mu \mathrm{M}$. Noteworthy, DMSO had no significant effect on cell viability (Fig. 2 A, Fig. 3 B). All the other treatments facilitated much lower DMSO concentrations.

Next, we focused on the impact of the 1:1 combination of SAS and DHA. We found that the mixture of SAS and DHA had similar impact as single treatment of DHA (Fig. 3 A, D, E). The combination of the parent compounds reduced cell viability significant as well as DHA in a dose dependent manner (Fig. 3 E). Although it had not a significant advantage compared to the sole treatment of DHA based on our results of cell metabolism. Astonishingly, cells treated with the covalent bound hybrid of SAS and DHA termed AC254 showed an immense reduction of cell viability (Fig. 3 A, F). The hybrids impact was already obvious at low concentrations $(0,5 \mu \mathrm{M})$ and could only be increased slightly by increasing the compound's quantity (Fig. 3 F). It stays on a level of cell viability comparable to the effect of DHA when utilized on a very high concentration $(20 \mu \mathrm{M})$ (Fig. 3 D, F). The impact of DHA combined with SAS is significant potentiated by AC254 in all used concentrations (Fig. 3 E, F).

Taken together these results match to the previous findings in cell morphology and emphasize that linking SAS and DHA in a covalent manner can change the biological impact of these compounds on gliomas heavily.

\section{AC254 is a potent gliomatoxic compound}

The question remains which mechanisms contribute to the reduction in cell viability and changes in cell morphology. To investigate whether our so far detected effects of the new compound AC254 can be attributed to cell death or might have other reasons we performed a flow cytometry with the marker 7Amino-actinomycin (7-AAD) and annexin V. Therefore, cells were treated with $1 \mu \mathrm{M}$ of the compounds for 72 hours (Figure 4).

The results revealed that the non-treated cells as well as the cells treated with SAS, DHA and their combination were approximately $92 \%$ viable (Fig. 4 A, B). The composition of 7AAD and annexin V positive cells were in all of these groups more or less the same (Fig. 4 A, B). Whereas after the treatment with AC254 only about 78\% of the cells were still alive (Fig. 4 A, B). Cells treated with AC254 showed a significant higher amount of 7AAD and annexin $V$ positive cells. The quantity of 7AAD-positive and annexin V-negative cells was around 4 times more compared to control (Fig. 4 A, B). The amount of sole annexin $\mathrm{V}$ and both positive cells was about 2-3 times higher compared to the other groups (Fig. 4 A, B). These findings demonstrate that AC254 induces apoptosis as well as other ways of cell death. However, apoptosis seems to be the major part of the induced cell death. To verify these results we performed a morphological apoptosis assay with Hoechst staining (Fig. 4 C). Here, we found that treating glioma cells 
with AC254 led to nuclear bloating and nuclear fragmentation (Fig. 4 C). In summary these experiments underline that the reduction in cell viability and the changes in cell morphology can be attributed to the induction of cell death induced by AC254. Thus, AC254 can be considered a novel compound with cytotoxic potential to combat gliomas.

\section{AC254's effect on cell cycle}

Furthermore, we performed cell cycle analysis with the rodent cell line F98. For this cells were treated $2 \mathrm{~h}$ after plating for duration of 72h, fixated and stained for 7AAD (Figure 5). Under controlled conditions about $55 \%$ of the cells were in G0- and G1-phase, around 7\% were in S-phase and another 39\% were located in the G2- and M-phase (Fig. 5 A). Between cells treated with SAS, DHA, their 1:1 mixture and nontreated cells there was no significant difference visible (Fig. 5 A, B). However the treatment with AC254 showed a significant change in cell cycle. There was a massive increase of cells in G0- and G1-phase (Fig. 5 A) which indicates that AC254 stops cells from being part of cell division. Another hint at this was the significant reduction of cells in G2- and M-phase after being treated with AC254 (Fig. 5 A, B). Taken together these findings show that the hybrid AC254 does not only lead to cell death but also slows down cell replication while its parent compounds or combination do not display such effects.

\section{Time of duration matters}

Because we detected morphological changes after treatment with AC254 already after 24h we wanted to investigate whether time matters for the gliomatoxic effect. Hence cell death and cell cycle analysis were repeated after 24 hours with a $1 \mu \mathrm{M}$ treatment on rodent cells (Figure 6). The results showed no increase in early apoptosis and cell death in general for all treatment groups compared to cells under controlled conditions (Fig. 6 A, B). We further investigated the cell cycle after 24 hours of treatment. As expected SAS, DHA and their combination did not change cell cycle compared to control (Fig. 6 C). Interestingly, AC254 showed only a significant increase of G0- and G1-phase while the changes of the other phases are not significant (Fig. 6 C). All in all these experiments indicate that the mechanisms leading to cell death take more than $24 \mathrm{~h}$ in the case of the compound $\mathrm{AC} 254$ to unfold its gliomatoxic effect.

\section{AC254 acts chemotherapeutic on human glioma cells}

Next, we examined the impact of our substances on human glioma cells. Therefore, we treated U87 with SAS, DHA, AC254 and the combination of the single compounds with different concentrations $(0,5 \mu \mathrm{M}, 1$ $\mu \mathrm{M}, 5 \mu \mathrm{M}, 10 \mu \mathrm{M}$ and $20 \mu \mathrm{M}$ ) for 72 hours (Figure 7). The first step was to view cell viability. All used treatments except for SAS reduced the cell viability significantly (Fig. 7). SAS showed a minor and in most cases statistically no significant impact on both human glioma cell lines in all used concentration (maximum $20 \mu \mathrm{M}$ ) (Fig. 7 A, B). Whereas DHA reduced cell viability in a dose-dependent manner significantly beginning already at the lowest used concentration $(0,5 \mu \mathrm{M})($ Fig. $7 \mathrm{~A}, \mathrm{~B})$. When treating cells with a combination of SAS and DHA the cells showed almost the same level of reduction in cell viability as cells treated with sole DHA (Fig. 7 A, B). Raising the concentration increased the effect of the treatment. Noteworthy, the hybrid AC254 was most effective in reducing the cell viability especially in low 
concentration (Fig. 7 A, B). At the concentration of $1 \mu \mathrm{M}$ and $5 \mu \mathrm{M}$ AC254 reduced cell viability significantly compared to the impact of all other treatment groups (Fig. 7 A, B). In higher concentrations $(10 \mu \mathrm{M}, 20 \mu \mathrm{M})$ there was no significant difference visible comparing AC254 treatment to DHA and its combination with SAS (Fig. 7 B). Whereas DHA operated in a strong dose-dependent manner AC254 did only amplify its impact on human glioma cells mildly when increasing its concentration (Fig. 7 B). We further had a look at cell confluence after treating the cells with all compounds. Despite the effect in cell viability we could not detect a difference in confluence comparing the treatments with the control (Fig. 8 A). Likewise, staining the cells for actin filaments and nuclei did not show any effects of the compounds regarding actin polymerization at 24 hours and at $5 \mu \mathrm{M}$ (Fig. 8 B).

To strengthen these results we examined the impact of all compounds on another human glioma cells line (TN22) for a single dose $(5 \mu \mathrm{M})$. We checked cell viability and morphology (Fig. 7 C, D). Cells treated with SAS showed no difference compared to control regarding cell viability whereas the treatment with sole DHA and the combinatorial treatment with SAS showed a significant reduction in cell viability at the same level (Fig. 7 D). The hybrid AC254 was even more effective reducing cell viability on this cell line compared to its impact on the other human cells (Fig. 7 B, D). Interestingly using light microscopy there was a difference in cell confluence visible between cells treated with AC254 and cell under controlled conditions (Fig. 7 C). In summary, these results confirm our former findings on rodent glioma cells though we detected a difference in efficiency between the different cell lines. SAS does not seem to be a gliomatoxic agent in low dose whereas DHA and especially the covalent bound hybrid of SAS and DHA seems to be highly potent at killing glioma cells.

\section{Impact on cell migration and glioma invasive growth}

Another important property especially for anti-glioma drugs is to suppress cell migration. Hence, we plated rodent cells into a 12-well plate, after $36 \mathrm{~h}$ a scratch was made, afterwards cell were treated with $0,5 \mu \mathrm{M}$ (Fig. 9 A) and $5 \mu \mathrm{M}$ (Fig. 9 B, C) of the compounds and monitored at various times. 12 hours after the treatment the gap between the cells representing the migration distance in all treatment groups and both concentrations was similar (Fig. 9 A, B, C). It took minimum 24h for the hybrid AC254 to achieve a small advantage over the control and the other treatments in both concentrations (Fig. 9 A, B, C). After $48 \mathrm{~h}$ the treatment with AC254 showed significant more impact on glioma cell migration than the control while the other treatments including SAS, DHA and their combination treatment seemed to have no effect when using the smaller concentration of 0,5 $\mathrm{MM}$ (Fig. 9 A). While AC254 was effective in both concentrations, DHA and the mixture of DHA and SAS decreased the cell migration only in higher concentration ( $5 \mu \mathrm{M})$ (Fig. 9 A, B, C). However, the treatment with AC254 seemed to be most potent against cell migration than all other treatments in both used concentrations.

To emphasize this point we performed another experiment assaying cell migration with a human glioma cell line (Figure 10). Cells were colonized and treated with $5 \mu \mathrm{M}$ of the different compounds. The migration distance was measured at various times. As well as in the previous cell migration assay SAS did not show a reduction of cell migration at any time (Fig. 10 A, B). Interestingly, DHA and the 1:1 mixture 
of DHA and SAS did not change cell migration as well (Fig. 10 A, B). Only the hybrid AC254 decreased cell migration significantly compared to control after $96 \mathrm{~h}$ (Fig. $10 \mathrm{~A}, \mathrm{~B}$ ). The longer period of time which was needed for AC254 to show its full effect on the human glioma cells compared to the rodent can be explained by U87 growing slower than F98 in general.

In summary, the new hybrid inhibits cell migration which is a very important trait for anti-cancer drugs especially regarding primary brain tumors.

\section{Primary neurons and astrocytes}

The next step was to investigate whether the compounds show any effect on healthy brain cells. Therefore, primary neurons and astrocytes were isolated from rodent brain and treated with two different concentrations of all compounds (Figure 11).

First we performed a cell viability assay for $1 \mu \mathrm{M}$ and $5 \mu \mathrm{M}$ after $72 \mathrm{~h}$. There we found no or only a minor difference in cell viability comparing the different treatments with the cell viability under controlled conditions (Figure 11 A, D). Furthermore, we stained the cells for propidium iodide (PI). SAS did not show any impact on primary neurons and astrocytes in both used concentrations (Fig. 11 B, C, E). After treating the cells with DHA, the combination of DHA and SAS and the hybrid AC254 we detected a higher amount of PI positive cells already when using $1 \mu \mathrm{M}$ (Fig. 11 B). This effect increased after treatment with a higher concentration of these compounds (Fig. 11 C, E). The impact on primary neurons and astrocytes caused by AC254 seemed to be smaller than the effect on cell death by the combinatorial treatment of DHA and SAS (Fig. $11 \mathrm{E})$.

Altogether except for SAS all used compounds show negative side effects on healthy brain cells.

\section{Discussion}

In general, the aim of chemotherapy is killing malignant cells while not harming the surrounding nontransformed cells. In neurooncology glioma cells represent the therapeutic targets and drugs should be facilitated at concentrations where normal healthy tissue (e.g. neurons, astrocytes) has the chance to survive. This cytotoxic strategy therefore depends on compounds which fulfill the requirements to be specifically toxic to cancer cells. Another strategy is to combine two effective anti-tumor agents in order to keep the necessary amount of chemotherapeutic substance as low as possible. In this study we combined these two methods especially. Two well-known substances with a long clinical use were bound together covalently. One of the promising molecule is dihydroartemisinin (DHA). DHA is a derivate of the natural antimalarial compound artemisinin. Despite its anti-malaria effects ${ }^{24}$ DHA has already proofed being an effective agent against various types of malignant tumors such as colorectal cancer ${ }^{25}$, lung carcinoma $^{26}$, ovarian cancer ${ }^{27}$, leukemia ${ }^{28,29}$, osteosarcoma ${ }^{30}$, prostate cancer ${ }^{31}$, hepatocellular cancer ${ }^{32}$ and pancreatic cancer ${ }^{33}$. There are reported studies in which DHA treatment was combined with other chemotherapeutic drugs, they showed that DHA can potentiate the effect of single drug treatment ${ }^{26,27}$. 
The mechanism of its properties is not fully understood yet but probably consist of the induction of apoptosis $^{26,27,29,30,33,31,32}$, cell cycle arrest ${ }^{32,26,33}$, anti-angiogenetic effects ${ }^{34-36}$ and reduction of migration ${ }^{30}$. As good sister molecule appeared sulfasalazine (SAS). SAS as well as DHA has a long clinical history and is commonly used for inflammatory diseases such as ulcerative colitis and rheumatic arthritis ${ }^{37,38}$. In the past it has already shown some important properties especially when dealing with brain tumors. SAS inhibits the glutamate transporter $\mathrm{xCT}$ which is an essential oncogene in brain tumors and other tumor entities $44,53,41$, it shows peritumoral anti-epileptic activity ${ }^{54}$ and is effective in alleviating tumor-induced brain swelling ${ }^{39}$. To get reliable data we investigated the impact of SAS and DHA on various glioma cells as single compounds, in combination with a ratio of 1:1 mixture of both single drugs and as a chemical linked hybrid of SAS and DHA termed AC254. Our experiments showed that SAS has no or only a minor effect on glioma cells regarding cell morphology, cell viability, cell death, cell cycle and cell migration in low concentrations. These findings match previous results on glioma cells ${ }^{39}$. In turn, we found DHA to reduce cell viability significantly already in low concentration.

The combinatorial treatment of SAS and DHA showed no significant improvement to sole treatment with DHA in all our settings which leads to the conclusion that the combination of uncombined SAS and DHA has no benefit in therapy. Astonishingly, linking SAS and DHA together chemically potentiated the effect of DHA treatment significantly. AC254 the hybrid of SAS and DHA led to immense reduction of cell viability which we can be attributed to cell death especially apoptosis and an arrest in cell cycle. Another trait of AC254 is the inhibition of cell migration which is a very important property to combat malignant tumors especially gliomas which tend to disseminate throughout the brain.

Summarizing, this study shows that it is possible to amplify an anti-glioma drugs' properties by linking it to another drug or biologically active compound.

\section{Declarations}

\section{AUTHORS' CONTRIBUTION}

N.E.S. and S.B.T conceived the research. A.Ç. and S.B.T. designed the compounds for biological studies. The chemical synthesis was performed by A.Ç. and supervised by S.B.T. All bioassays were performed by A.A., who also analysed and interpreted the experiments with help from N.E.S. and M.B. The manuscript was written through contributions of all authors. All authors have given approval to the final version of the manuscript. A.A. performed the present work in fulfilment of the requirements for obtaining the degree Dr. med. at the Medical Faculty of the Friedrich-Alexander University of Erlangen-Nürnberg (FAU).

\section{ACKNOWLEDGEMENTS}

We gratefully acknowledge the financial support from Deutsche Forschungsgemeinschaft (DFG) by grants TS 87/16-3 and TS 87/23-1. We also thank the Interdisciplinary Center for Molecular Materials (ICMM), the Graduate School Molecular Science (GSMS) for research support, as well as Emerging Fields 
Initiative (EFI) "Chemistry in Live Cells" supported by Friedrich-Alexander-Universität Erlangen-Nürnberg for funding. Financial support by the German Academic Exchange Service (DAAD) for doctoral research fellowship for Aysun Çapcı is gratefully acknowledged. We thank Carmen Christoph (Department of Psychiatry, Universitätsklinikum Erlangen) for the supply of primary neurons and astrocytes and Tina Sehm (Translational Cell Biology \& Neurooncology Lab, Department of Neurosurgery, Universitätsklinikum Erlangen) for generating and providing the human glial cells TN22.

\section{CONFLICT OF INTEREST}

The authors declare no competing financial conflict of interests.

\section{ETHICAL STATEMENT}

All methods were carried out in accordance with relevant guidelines and regulations.

Animal killing was performed in accordance with the German Protection of Animals Act 14 paragraph one and three. The announcement of rat and mouse killing was approved by the designee for animal protection of the University of Erlangen-Nuremberg (TS-7/12). The study was carried out in compliance with the ARRIVE guidelines.

Studies with human tissue were conducted in compliance with the Helsinki Declaration and approved by the Ethics Committee of the Friedrich Alexander University of Erlangen-Nuremberg. All patients gave written informed consent to donate tissue for participate in the study.

\section{References}

1. Eyüpoglu IY, Buchfelder M, Savaskan NE. Surgical resection of malignant gliomas-role in optimizing patient outcome. Nat Rev Neurol. 2013;9(3):141-151. doi:10.1038/nrneurol.2012.279

2. Stupp R, Brada M, van den Bent MJ, Tonn J-C, Pentheroudakis G. High-grade glioma: ESMO Clinical Practice Guidelines for diagnosis, treatment and follow-up. Ann Oncol. 2014;25 Suppl 3:iii93-101. doi:10.1093/annonc/mdu050

3. Lim M, Xia Y, Bettegowda C, Weller M. Current state of immunotherapy for glioblastoma. Nat Rev Clin Oncol. 2018;15(7):422-442. doi:10.1038/s41571-018-0003-5

4. Brem S, Cotran R, Folkman J. Tumor angiogenesis: a quantitative method for histologic grading. $J$ Natl Cancer Inst. 1972;48(2):347-356.

5. Mehta G, Singh V. Hybrid systems through natural product leads: an approach towards new molecular entities. Chem Soc Rev. 2002;31(6):324-334.

6. Tietze LF, Bell HP, Chandrasekhar S. Natural product hybrids as new leads for drug discovery. Angew Chem Int Ed Engl. 2003;42(34):3996-4028. doi:10.1002/anie.200200553 
7. Ganesan A. Natural products as a hunting ground for combinatorial chemistry. Curr Opin Biotechnol. 2004;15(6):584-590. doi:10.1016/j.copbio.2004.09.002

8. Meunier B. Hybrid molecules with a dual mode of action: dream or reality? Acc Chem Res. 2008;41(1):69-77. doi:10.1021/ar7000843

9. Tsogoeva SB. Recent progress in the development of synthetic hybrids of natural or unnatural bioactive compounds for medicinal chemistry. Mini Rev Med Chem. 2010;10(9):773-793.

10. Fröhlich T, Çapcı Karagöz A, Reiter C, Tsogoeva SB. Artemisinin-Derived Dimers: Potent Antimalarial and Anticancer Agents. J Med Chem. 2016;59(16):7360-7388. doi:10.1021/acs.jmedchem.5b01380

11. Ackermann A, Karagöz AÇ, Ghoochani A, et al. Cytotoxic profiling of artesunic and betulinic acids and their synthetic hybrid compound on neurons and gliomas. Oncotarget. 2017;8(37):61457-61474. doi:10.18632/oncotarget.18390

12. Mariani A, Mai TT, Zacharioudakis $E$, et al. Iron-dependent lysosomal dysfunction mediated by a natural product hybrid. Chem Commun (Camb ). 2016;52(7):1358-1360. doi:10.1039/c5cc09255h

13. Reiter C, Capcı Karagöz A, Fröhlich T, et al. Synthesis and study of cytotoxic activity of 1,2,4-trioxaneand egonol-derived hybrid molecules against Plasmodium falciparum and multidrug-resistant human leukemia cells. Eur J Med Chem. 2014;75:403-412. doi:10.1016/j.ejmech.2014.01.043

14. Reiter C, Herrmann A, Çapci A, Efferth T, Tsogoeva SB. New artesunic acid homodimers: potent reversal agents of multidrug resistance in leukemia cells. Bioorg Med Chem. 2012;20(18):5637-5641. doi:10.1016/j.bmc.2012.07.015

15. Reiter C, Fröhlich T, Gruber L, et al. Highly potent artemisinin-derived dimers and trimers: Synthesis and evaluation of their antimalarial, antileukemia and antiviral activities. Bioorg Med Chem. 2015;23(17):5452-5458. doi:10.1016/j.bmc.2015.07.048

16. Reiter $C$, Fröhlich $T$, Zeino $M$, et al. New efficient artemisinin derived agents against human leukemia cells, human cytomegalovirus and Plasmodium falciparum: 2nd generation 1,2,4-trioxane-ferrocene hybrids. Eur J Med Chem. 2015;97:164-172. doi:10.1016/j.ejmech.2015.04.053

17. Fröhlich T, Kiss A, Wölfling J, et al. Synthesis of Artemisinin-Estrogen Hybrids Highly Active against HCMV, P. falciparum, and Cervical and Breast Cancer. ACS Med Chem Lett. 2018;9(11):1128-1133. doi:10.1021/acsmedchemlett.8b00381

18. Karagöz AÇ, Leidenberger M, Hahn F, et al. Synthesis of new betulinic acid/betulin-derived dimers and hybrids with potent antimalarial and antiviral activities. Bioorg Med Chem. 2019;27(1):110-115. doi:10.1016/j.bmc.2018.11.018

19. Tu Y. The discovery of artemisinin (qinghaosu) and gifts from Chinese medicine. Nat Med. 2011;17(10):1217-1220. doi:10.1038/nm.2471

20. Hamacher-Brady A, Stein HA, Turschner S, et al. Artesunate activates mitochondrial apoptosis in breast cancer cells via iron-catalyzed lysosomal reactive oxygen species production. J Biol Chem. 2011;286(8):6587-6601. doi:10.1074/jbc.M110.210047

21. Efferth T, Giaisi M, Merling A, Krammer PH, Li-Weber M. Artesunate induces ROS-mediated apoptosis in doxorubicin-resistant T leukemia cells. PLOS ONE. 2007;2(8):e693. 
doi:10.1371/journal.pone.0000693

22. Eling N, Reuter L, Hazin J, Hamacher-Brady A, Brady NR. Identification of artesunate as a specific activator of ferroptosis in pancreatic cancer cells. Oncoscience. 2015;2(5):517-532. doi:10.18632/oncoscience.160

23. Sukhai MA, Prabha S, Hurren R, et al. Lysosomal disruption preferentially targets acute myeloid leukemia cells and progenitors. J Clin Invest. 2013;123(1):315-328. doi:10.1172/JCl64180

24. Guidelines for the Treatment of Malaria. 3rd. 2015.

25. Yao Z, Bhandari A, Wang Y, et al. Dihydroartemisinin potentiates antitumor activity of 5-fluorouracil against a resistant colorectal cancer cell line. Biochem Biophys Res Commun. 2018;501(3):636-642. doi:10.1016/j.bbrc.2018.05.026

26. Zhang B, Zhang Z, Wang J, et al. Dihydroartemisinin sensitizes Lewis lung carcinoma cells to carboplatin therapy via p38 mitogen-activated protein kinase activation. Oncol Lett. 2018;15(5):75317536. doi:10.3892/ol.2018.8276

27. Chen $T$, Li M, Zhang R, Wang $H$. Dihydroartemisinin induces apoptosis and sensitizes human ovarian cancer cells to carboplatin therapy. J Cell Mol Med. 2009;13(7):1358-1370. doi:10.1111/j.15824934.2008.00360.x

28. Li X, Gao Y, Zhang Q, et al. Dihydroartemisinin-regulated mRNAs and IncRNAs in chronic myeloid leukemia. Oncotarget. 2018;9(2):2543-2552. doi:10.18632/oncotarget.23274

29. Lu J-J, Meng L-H, Cai Y-J, et al. Dihydroartemisinin induces apoptosis in HL-60 leukemia cells dependent of iron and p38 mitogen-activated protein kinase activation but independent of reactive oxygen species. Cancer Biol Ther. 2008;7(7):1017-1023. doi:10.4161/cbt.7.7.6035

30. Liu Y, Wang W, Xu J, et al. Dihydroartemisinin inhibits tumor growth of human osteosarcoma cells by suppressing Wnt/ $\beta$-catenin signaling. Oncol Rep. 2013;30(4):1723-1730. doi:10.3892/or.2013.2658

31. He Q, Shi J, Shen X-L, et al. Dihydroartemisinin upregulates death receptor 5 expression and cooperates with TRAIL to induce apoptosis in human prostate cancer cells. Cancer Biol Ther. 2010;9(10):819-824. doi:10.4161/cbt.9.10.11552

32. Zhang CZ, Zhang H, Yun J, Chen GG, Lai PBS. Dihydroartemisinin exhibits antitumor activity toward hepatocellular carcinoma in vitro and in vivo. Biochem Pharmacol. 2012;83(9):1278-1289. doi:10.1016/j.bcp.2012.02.002

33. Chen $\mathrm{H}$, Sun $\mathrm{B}$, Wang $\mathrm{S}$, et al. Growth inhibitory effects of dihydroartemisinin on pancreatic cancer cells: involvement of cell cycle arrest and inactivation of nuclear factor-kappaB. J Cancer Res Clin Oncol. 2010;136(6):897-903. doi:10.1007/s00432-009-0731-0

34. Chen $\mathrm{H}-\mathrm{H}$, Zhou $\mathrm{H}-\mathrm{J}$, Fang $\mathrm{X}$. Inhibition of human cancer cell line growth and human umbilical vein endothelial cell angiogenesis by artemisinin derivatives in vitro. Pharmacol Res. 2003;48(3):231-236.

35. Chen H-H, Zhou H-J, Wang W-Q, Wu G-D. Antimalarial dihydroartemisinin also inhibits angiogenesis. Cancer Chemother Pharmacol. 2004;53(5):423-432. doi:10.1007/s00280-003-0751-4 
36. Wang S-J, Sun B, Cheng Z-X, et al. Dihydroartemisinin inhibits angiogenesis in pancreatic cancer by targeting the NF-kB pathway. Cancer Chemother Pharmacol. 2011;68(6):1421-1430. doi:10.1007/s00280-011-1643-7

37. Smolen JS, Landewé R, Bijlsma J, et al. EULAR recommendations for the management of rheumatoid arthritis with synthetic and biological disease-modifying antirheumatic drugs: 2016 update. Ann Rheum Dis. 2017;76(6):960-977. doi:10.1136/annrheumdis-2016-210715

38. Harbord M, Eliakim R, Bettenworth D, et al. Third European Evidence-based Consensus on Diagnosis and Management of Ulcerative Colitis. Part 2: Current Management. J Crohns Colitis. 2017;11(7):769-784. doi:10.1093/ecco-jcc/jjx009

39. Sehm T, Fan Z, Ghoochani A, et al. Sulfasalazine impacts on ferroptotic cell death and alleviates the tumor microenvironment and glioma-induced brain edema. Oncotarget. 2016;7(24):36021-36033. doi:10.18632/oncotarget.8651

40. Garcia CG, Kahn SA, Geraldo LHM, et al. Combination Therapy with Sulfasalazine and Valproic Acid Promotes Human Glioblastoma Cell Death Through Imbalance of the Intracellular Oxidative Response. Mol Neurobiol. 2018;55(8):6816-6833. doi:10.1007/s12035-018-0895-1

41. Chung WJ, Sontheimer $\mathrm{H}$. Sulfasalazine inhibits the growth of primary brain tumors independent of nuclear factor-kappaB. J Neurochem. 2009;110(1):182-193. doi:10.1111/j.1471-4159.2009.06129.x

42. Robe PA, Bentires-Alj $M$, Bonif $M$, et al. In vitro and in vivo activity of the nuclear factor-kappaB inhibitor sulfasalazine in human glioblastomas. Clin Cancer Res. 2004;10(16):5595-5603. doi:10.1158/1078-0432.CCR-03-0392

43. Sleire L, Skeie BS, Netland IA, et al. Drug repurposing: sulfasalazine sensitizes gliomas to gamma knife radiosurgery by blocking cystine uptake through system Xc-, leading to glutathione depletion. Oncogene. 2015;34(49):5951-5959. doi:10.1038/onc.2015.60

44. Gout PW, Buckley AR, Simms CR, Bruchovsky N. Sulfasalazine, a potent suppressor of lymphoma growth by inhibition of the $x(c)$ - cystine transporter: a new action for an old drug. Leukemia. 2001;15(10):1633-1640.

45. Lo M, Ling V, Low C, Wang YZ, Gout PW. Potential use of the anti-inflammatory drug, sulfasalazine, for targeted therapy of pancreatic cancer. Curr Oncol. 2010;17(3):9-16. doi:10.3747/co.v17i3.485

46. Nagane M, Kanai E, Shibata $Y$, et al. Sulfasalazine, an inhibitor of the cystine-glutamate antiporter, reduces DNA damage repair and enhances radiosensitivity in murine B16F10 melanoma. PLOS ONE. 2018;13(4):e0195151. doi:10.1371/journal.pone.0195151

47. Awasthi S, Sharma R, Singhal SS, Herzog NK, Chaubey M, Awasthi YC. Modulation of cisplatin cytotoxicity by sulphasalazine. Br J Cancer. 1994;70(2):190-194. doi:10.1038/bjc.1994.278

48. Ma M-Z, Chen G, Wang P, et al. Xc- inhibitor sulfasalazine sensitizes colorectal cancer to cisplatin by a GSH-dependent mechanism. Cancer Lett. 2015;368(1):88-96. doi:10.1016/j.canlet.2015.07.031

49. Narang VS, Pauletti GM, Gout PW, Buckley DJ, Buckley AR. Sulfasalazine-induced reduction of glutathione levels in breast cancer cells: enhancement of growth-inhibitory activity of Doxorubicin. Chemotherapy. 2007;53(3):210-217. doi:10.1159/000100812 
50. Müerköster S, Arlt A, Witt M, et al. Usage of the NF-kappaB inhibitor sulfasalazine as sensitizing agent in combined chemotherapy of pancreatic cancer. Int J Cancer. 2003;104(4):469-476. doi:10.1002/ijc.10963

51. Bus PJ, Nagtegaal ID, Verspaget HW, et al. Mesalazine-induced apoptosis of colorectal cancer: on the verge of a new chemopreventive era? Aliment Pharmacol Ther. 1999;13(11):1397-1402.

52. Wahl C, Liptay S, Adler G, Schmid RM. Sulfasalazine: a potent and specific inhibitor of nuclear factor kappa B. J Clin Invest. 1998;101(5):1163-1174. doi:10.1172/JCI992

53. Ji X, Qian J, Rahman SMJ, et al. XCT (SLC7A11)-mediated metabolic reprogramming promotes nonsmall cell lung cancer progression. Oncogene. 2018;37(36):5007-5019. doi:10.1038/s41388-0180307-z

54. Buckingham SC, Campbell SL, Haas BR, et al. Glutamate release by primary brain tumors induces epileptic activity. Nat Med. 2011;17(10):1269-1274. doi:10.1038/nm.2453

55. Friedlein $\mathrm{K}$, Bozhkov $\mathrm{Y}$, Hore N, et al. A new functional classification system (FGA/B) with prognostic value for glioma patients. Sci Rep. 2015;5:12373. doi:10.1038/srep12373

\section{Figures}

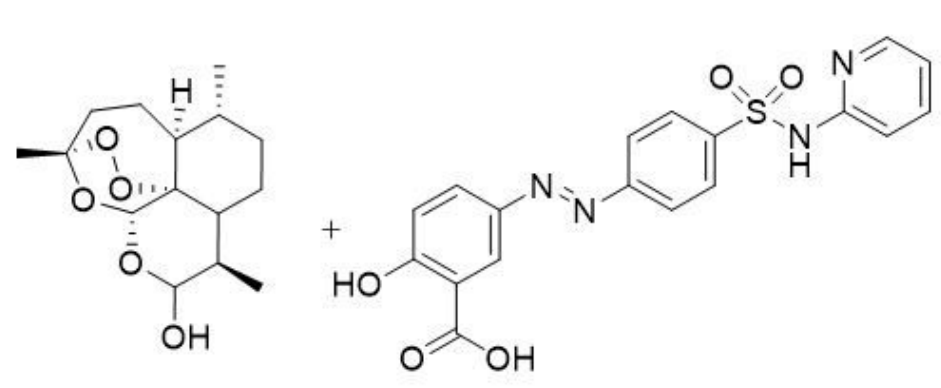

Dihydroartemisinin

Sulfasalazine

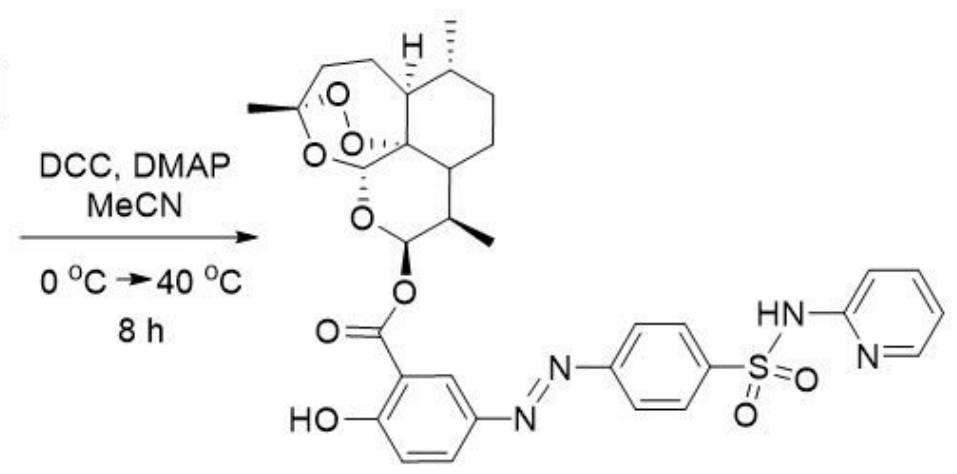

AC254

\section{Figure 1}

Synthesis route for the novel sulfasalazine-dihydroartemisinin hybrid AC254 


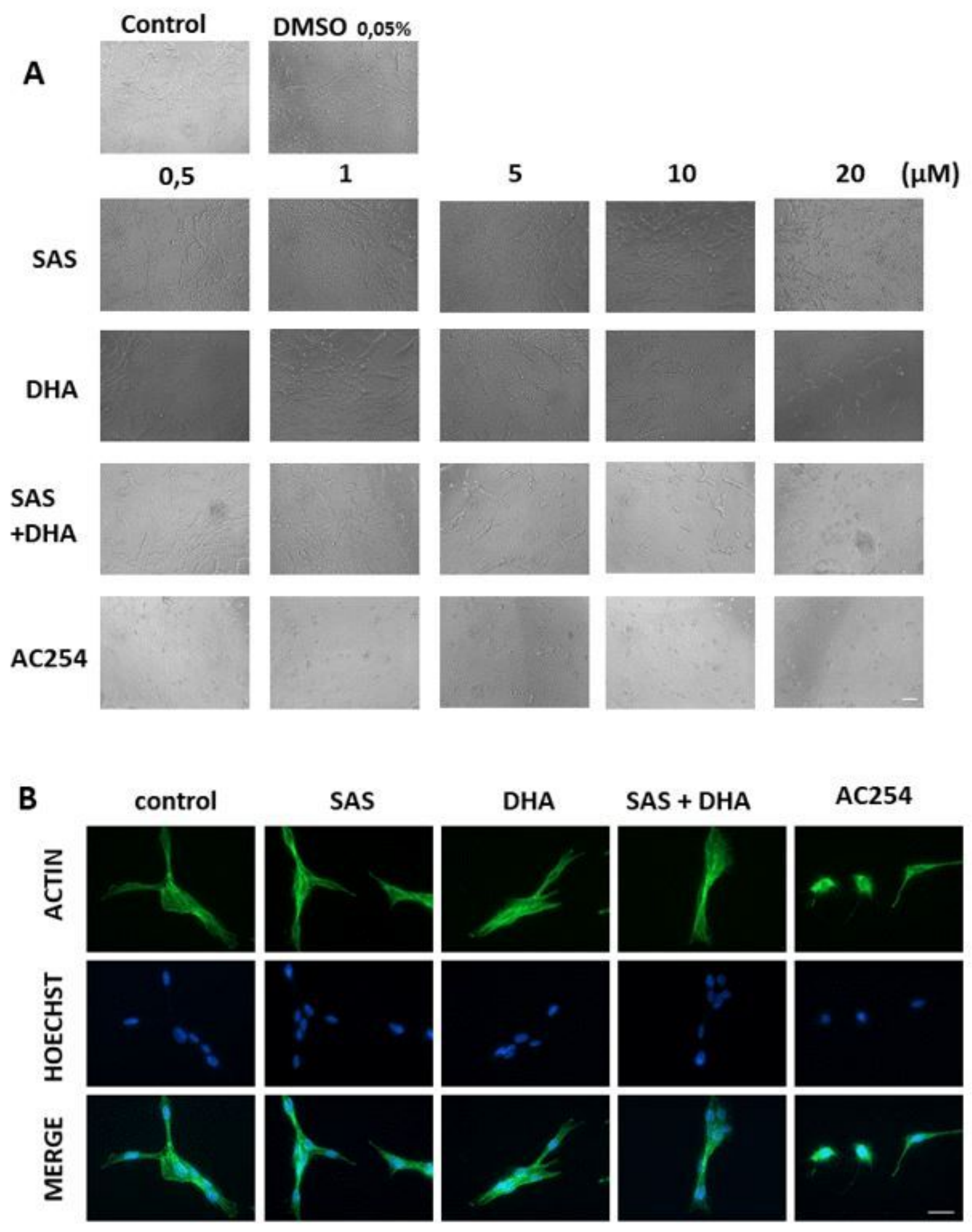

Figure 2

Morphologic profiling of Sulfasalazine, DHA and the novel heteromeric compound AC254 on rodent glioma cells A Rat glioma cells (F98) were treated with a range of concentrations of SAS, DHA, AC254, SAS and solvent DMSO combined with DHA. Cell morphology was examined after $72 \mathrm{~h}$ with light microscopy. Scale bar, $200 \mu \mathrm{M}$. B F98 were treated with 0,5 $\mu \mathrm{M}$ of SAS, DHA, AC254 and SAS combined 
with. Cells were fixated and stained with actin marker Phalloidin 488 and DNA marker Hoechst after 24h of treatment. Scale bar: $20 \mu \mathrm{m}$.
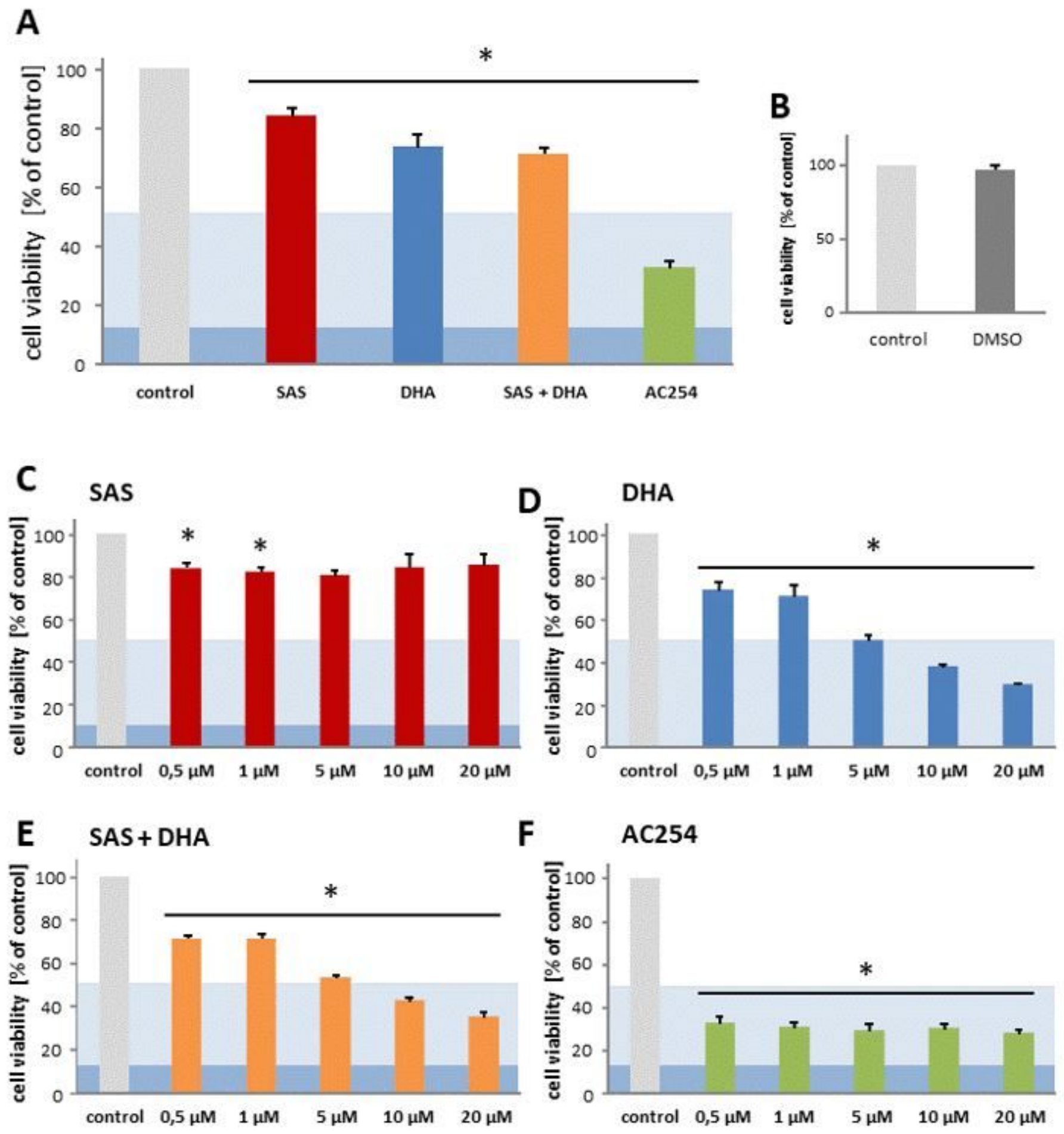

\section{Figure 3}

Cytotoxic profiling of Sulfasalazine, DHA and the novel sulfasalazine-dihydroartemisinin hybrid AC254 on rodent glioma cells A Cells were treated with $0,5 \mu \mathrm{M}$ of SAS, DHA, AC254 and the combination of SAS and DHA. Cell viability was measured after $72 \mathrm{~h}$. Statistical significance was tested with unpaired two-sided ttest vs. control ( $n \geq 4 ; *, p \leq 0.05)$. The light blue marking indicates the value of IC50 and the dark blue 
one stands for IC 90 value. This is passable for the following figures. B Cells were treated with $0,05 \%$ DMSO which represents the maximum concentration of DMSO achieved at the treatment with $20 \mu \mathrm{M}$ at the combinatorial treatment of SAS and DHA. At all other treatments the concentration of DMSO was less. Measurements were made after 72h. C-F Cells were treated the same way as in A with different concentrations of the compounds, SAS (C), DHA (D), SAS combined with DHA (E) and the hybrid AC254 (F). Statistical significance was tested with unpaired two-sided t-test vs. control $\left(n \geq 4 ;{ }^{*}, p \leq 0.05\right)$.

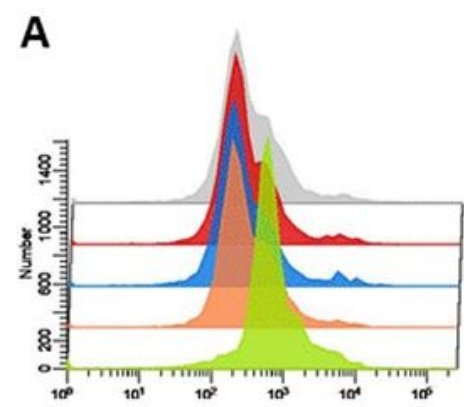

7 AAD

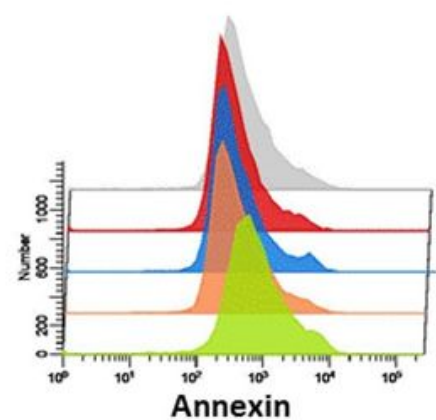

Annexin

\begin{tabular}{|llll|}
\hline$[\% \pm$ SEM] & sole $7 \mathrm{AAD}$ & sole Annexin & $7 \mathrm{AAD}+$ Annexin \\
\hline control & $1,1 \pm 0,1$ & $2,4 \pm 0,2$ & $4,7 \pm 0,4$ \\
\hline SAS & $1,2 \pm 0,2$ & $1,9 \pm 0,2$ & $4,6 \pm 0,4$ \\
\hline DHA & $1,2 \pm 0,1$ & $2 \pm 0,1$ & $4,7 \pm 0,7$ \\
\hline SAS + DHA & $1,2 \pm 0,2$ & $2,1 \pm 0,2$ & $4,3 \pm 0,2$ \\
\hline AC254 & $4,4 \pm 0,3^{*}$ & $6,7 \pm 1,2^{*}$ & $10,6 \pm 0,9^{*}$ \\
\hline
\end{tabular}

B
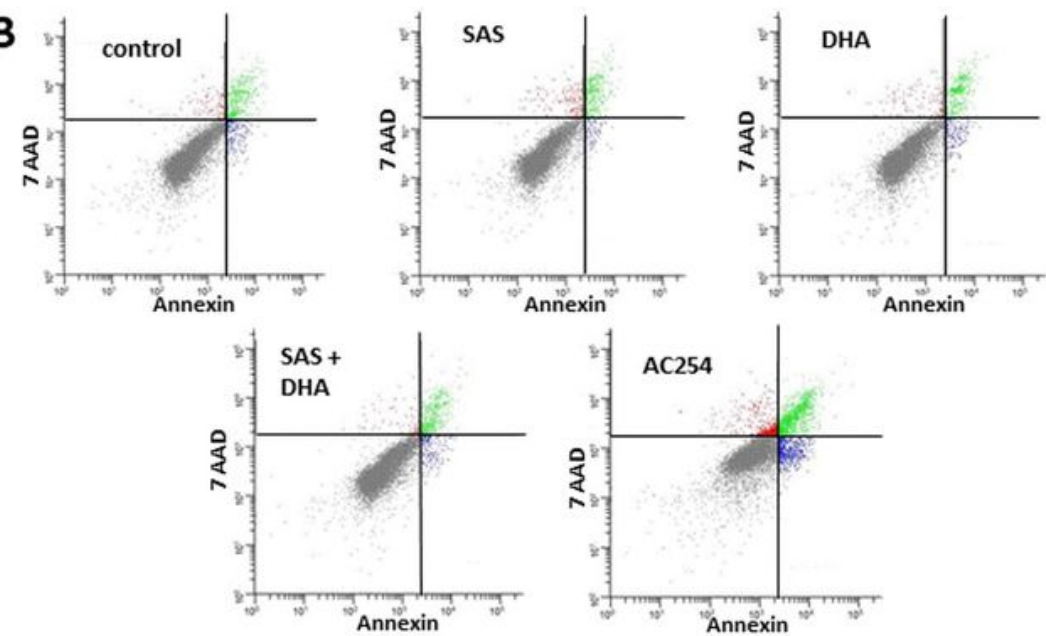

C

control

AC254
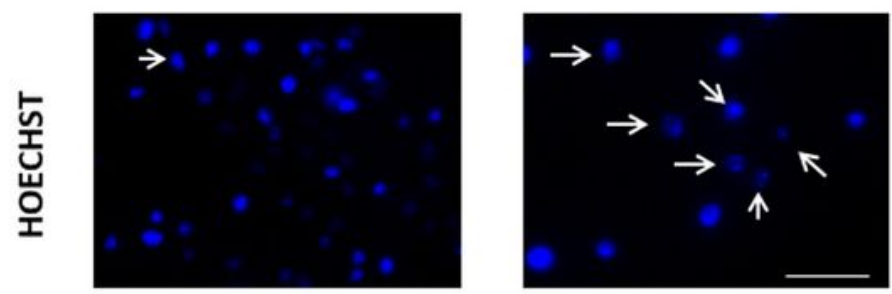

Figure 4 
Cell death analysis of gliomas after of gliomas following application of compounds A,B F98 rodent glioma cells ( 100.000 cells/well; 6 well) were treated with $1 \mu \mathrm{M}$ of the compounds. Cell death analysis was performed after $72 \mathrm{~h}$ with $7 \mathrm{AAD}$ and Annexin $\mathrm{V}$. Statistical significance was tested with unpaired twosided t-test vs. control $(n \geq 5 ; *, p \leq 0.05)$. C F98 were treated the same was as in A,B. After $72 h$ F98 were collected and stained for the DNA marker Hoechst. Scale bar, $50 \mu \mathrm{m}$.
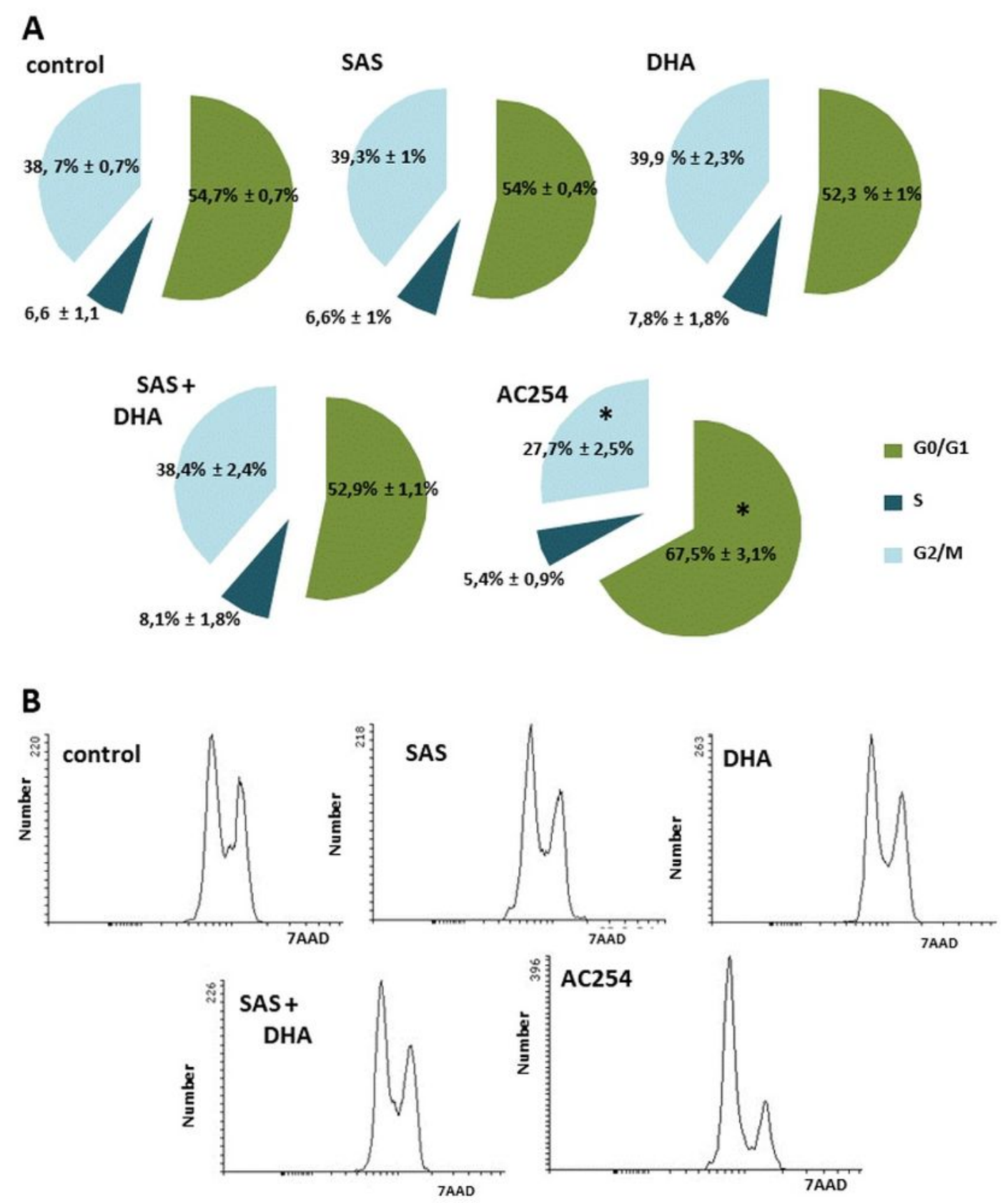

Figure 5 
Cell cycle analysis after $72 \mathrm{~h}$ of treatment A,B F98 (100,000 cells/well; 6 well) were treated with $1 \mu \mathrm{M}$ of SAS, DHA, AC254 and the combination of SAS and DHA . Cell cycle analysis was performed after $72 \mathrm{~h}$ after fixation and staining with 7AAD. Statistical significance was tested with unpaired two-sided t-test vs. control $(n \geq 5 ; *, p \leq 0.05)$.

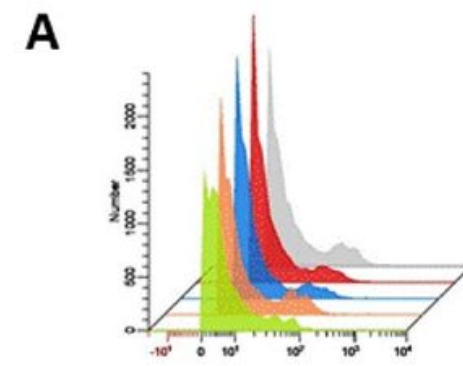

7 AAD

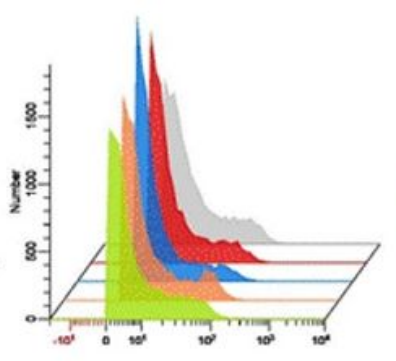

Annexin

\begin{tabular}{|llll|}
\hline$[\% \pm S E M]$ & $7 A A D$ & Annexin & $7 A A D+$ Annexin \\
\hline control & $4,1 \pm 1,8$ & $4,5 \pm 0,4$ & $7,0 \pm 0,5$ \\
\hline SAS & $4,3 \pm 1,8$ & $3,0 \pm 0,7$ & $6,0 \pm 0,2$ \\
\hline DHA & $4,2 \pm 1,1$ & $2,8 \pm 0,5$ & $8,4 \pm 2,1$ \\
\hline SAS + DHA & $5,1 \pm 1,2$ & $3,1 \pm 0,5$ & $6,5 \pm 1,4$ \\
\hline AC254 & $3,4 \pm 0,3$ & $4,1 \pm 0,6$ & $7,9 \pm 0,7$ \\
\hline
\end{tabular}
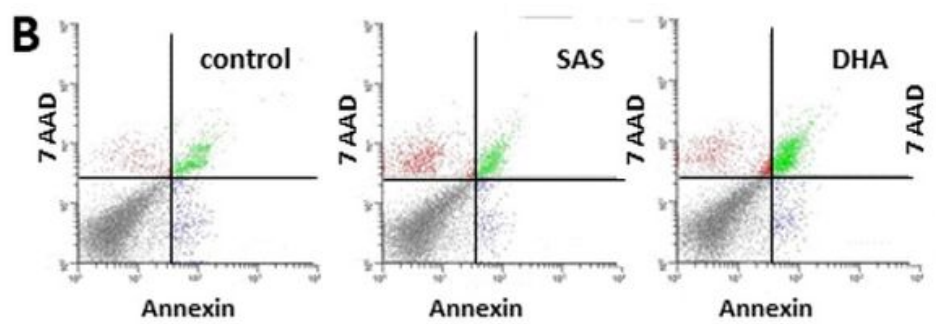

Annexin
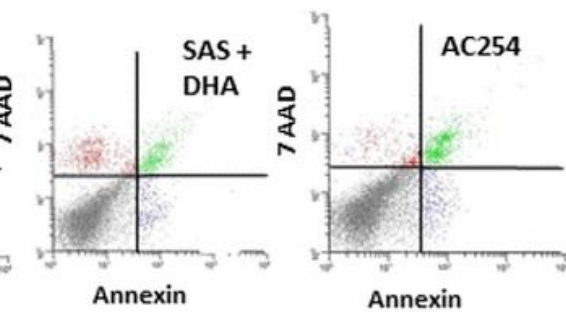

C
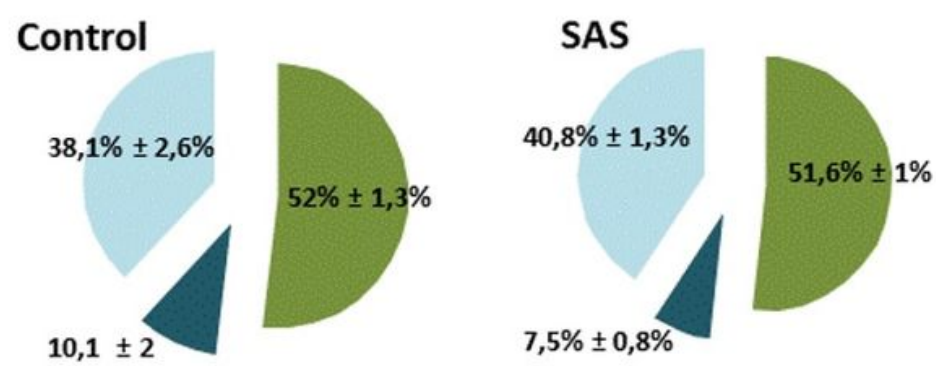

\section{DHA}
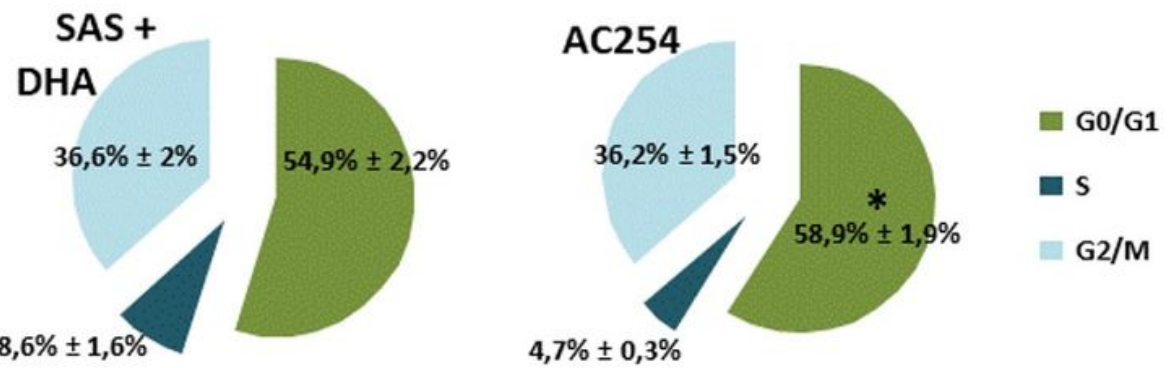

\section{Figure 6}

Cell death analysis and cell cycle after $24 \mathrm{~h}$ of treatment A, B Rodent cells ( 200.000 cells/well; 6 well) were treated with $1 \mu \mathrm{M}$ of the compounds. Cell death analysis was performed after 24h with 7 AAD and 
Annexin V. Statistical significance was tested with unpaired two-sided t-test vs. control $(n=3 ; *, p \leq 0.05)$.
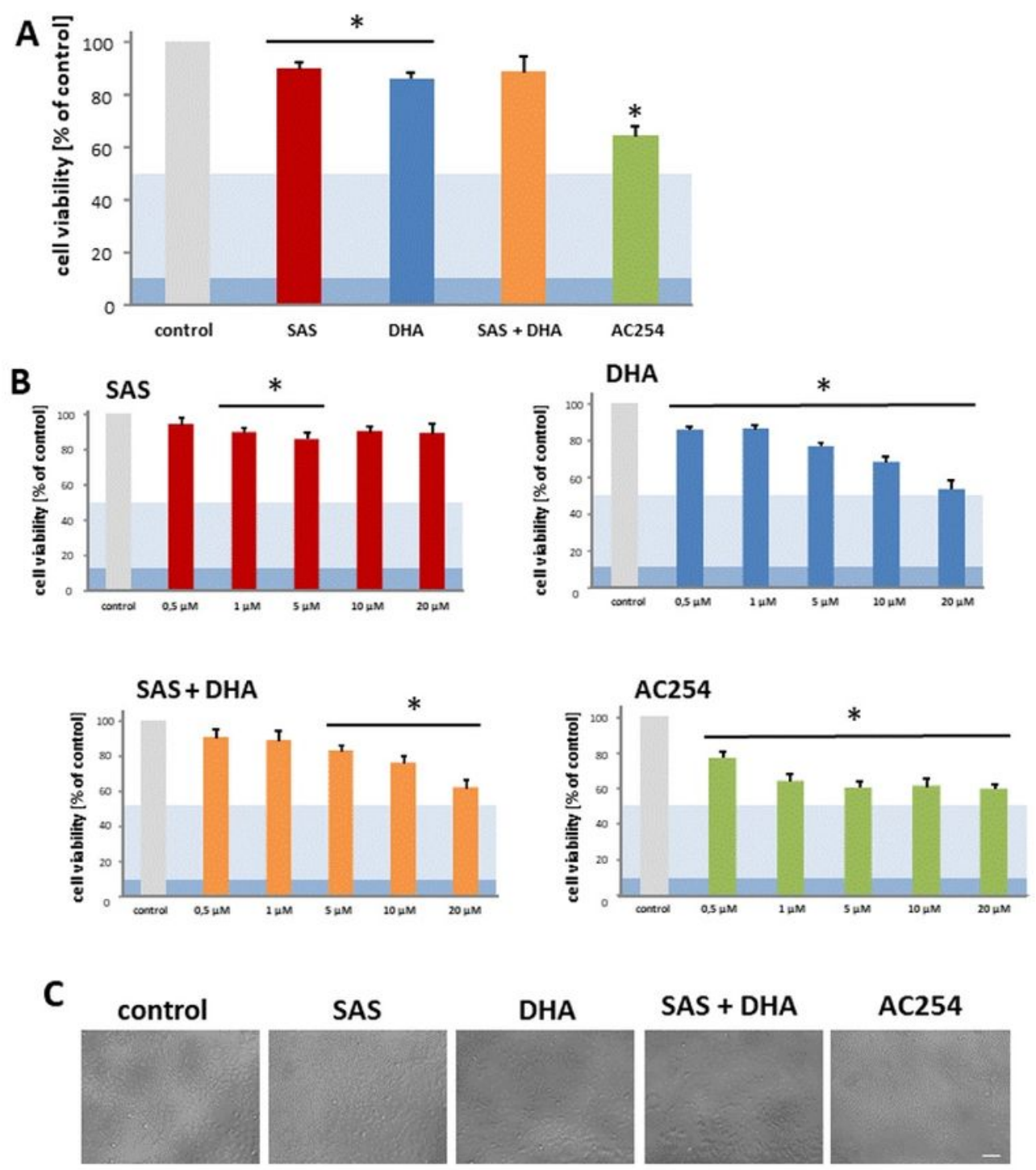

AC254

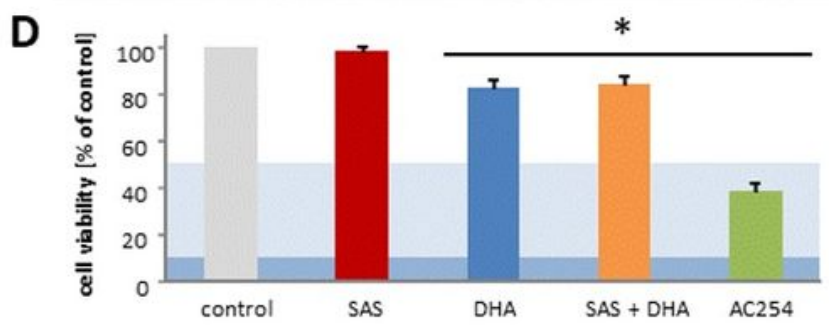

\section{Figure 7}

Effects on human cell viability (U87, TN22) A Cells (U87) were treated with $1 \mu \mathrm{M}$ of the compounds. Cell viability was measured after $72 \mathrm{~h}$. Statistical significance was tested with unpaired two-sided t-test vs. control $(n=4 ; *, p \leq 0.05)$. B U87 were treated with various concentrations of the substances. Cell viability was measured the same way as in A. Statistical significance was tested with unpaired two-sided t-test vs. 
control ( $n=4 ; *, p \leq 0.05)$. C TN22 were treated with $5 \mu \mathrm{M}$ of the compounds. Cell morphology was examined after $72 \mathrm{~h}$ with light microscopy. Scale bar, $200 \mu \mathrm{m}$. D TN22 were treated with $5 \mu \mathrm{M}$ of the compounds, cell viability was measured after $72 \mathrm{~h}$. Statistical significance was tested with unpaired twosided t-test vs. control $(n=4 ; *, p \leq 0.05)$.

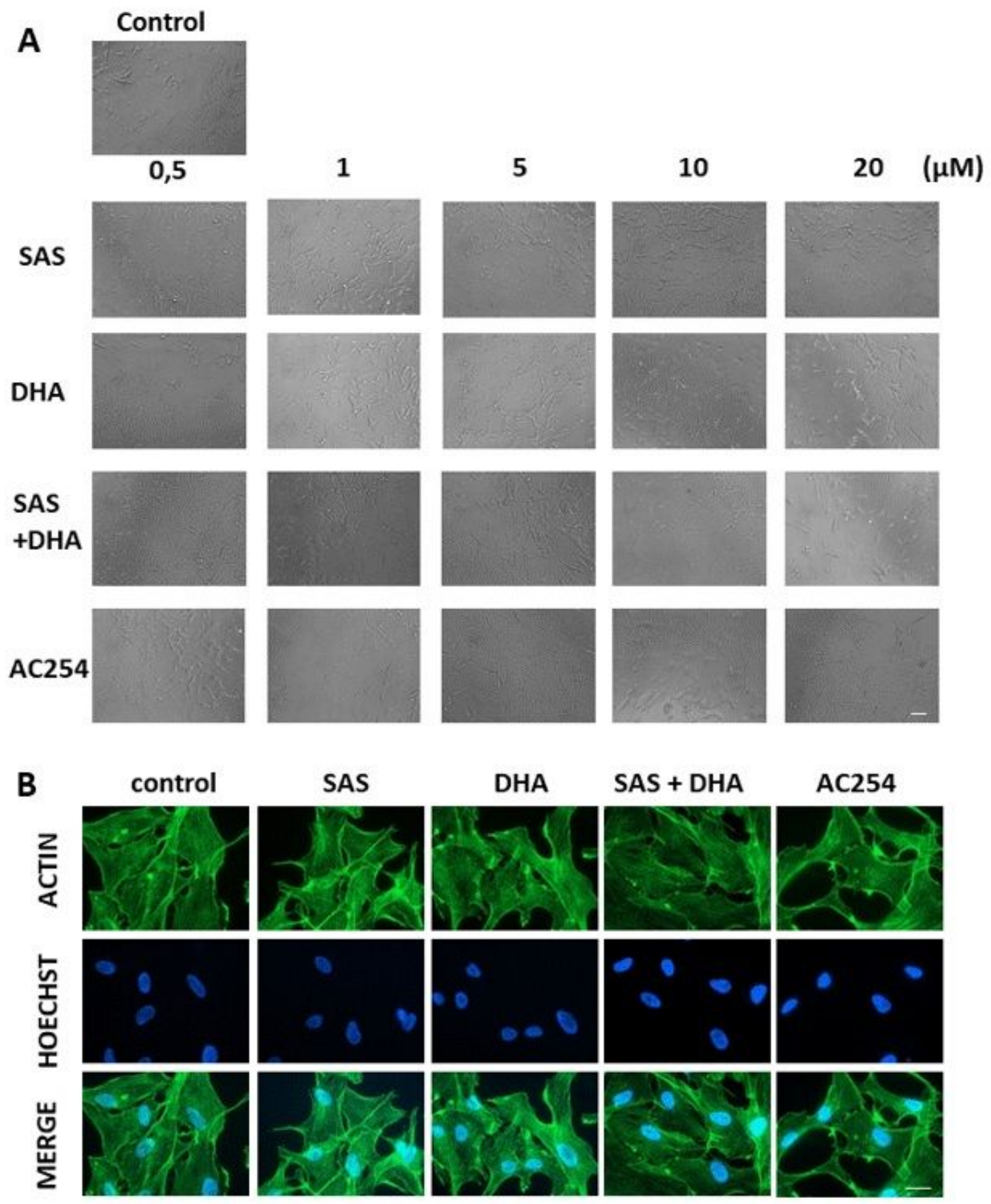

Figure 8 
Impact on human cell morphology A Human cells (U87) were treated with a variation of concentrations of SAS, DHA, their covalent bound hybrid (AC254) and their 1:1 mixture. Cell morphology was examined after $72 \mathrm{~h}$ with light microscopy. Scale bar, $200 \mu \mathrm{M}$. B Cells (U87) were treated with $5 \mu \mathrm{M}$ of SAS, DHA, AC254 and SAS combined with. Cells were fixated and stained with actin marker Phalloidin 488 and DNA marker Hoechst after 24h of treatment. Scale bars represents $20 \mu \mathrm{m}$.
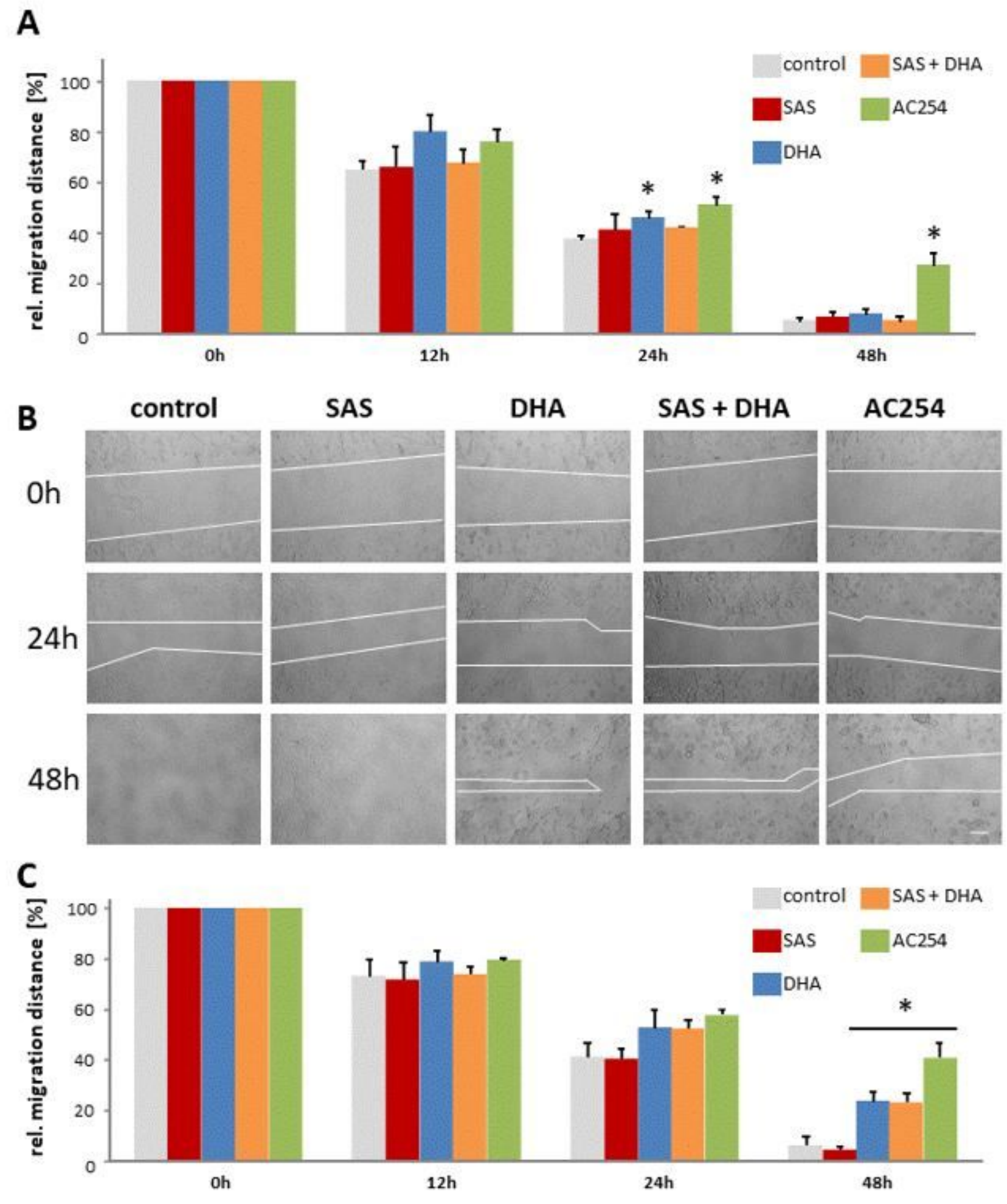

Figure 9 
Impact of the substances on cell migration A, B, C A scratch was made into plated cells (F98) after 36h. Cells were then treated with $0,5 \mu \mathrm{M}(\mathrm{A})$ and $5 \mu \mathrm{M}(\mathrm{B}, \mathrm{C})$ of the compounds. Representative images were taken (B), quantified and related to the time the scratch was made (Oh) $(A, C)$. Statistical significance was tested with unpaired two-sided t-test vs. control $\left(n=3 ;{ }^{*}, p \leq 0.05\right)$.

A

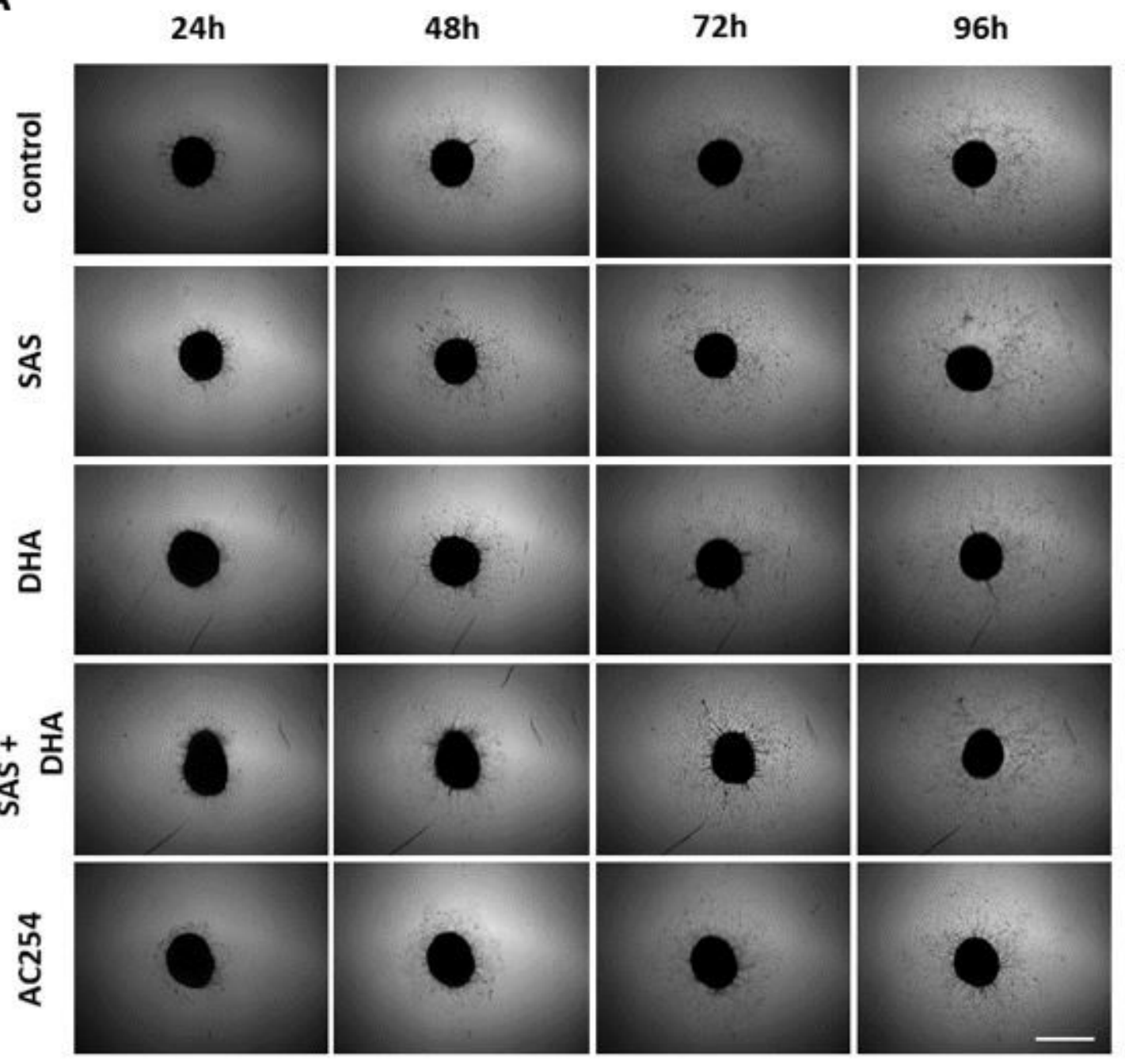

B

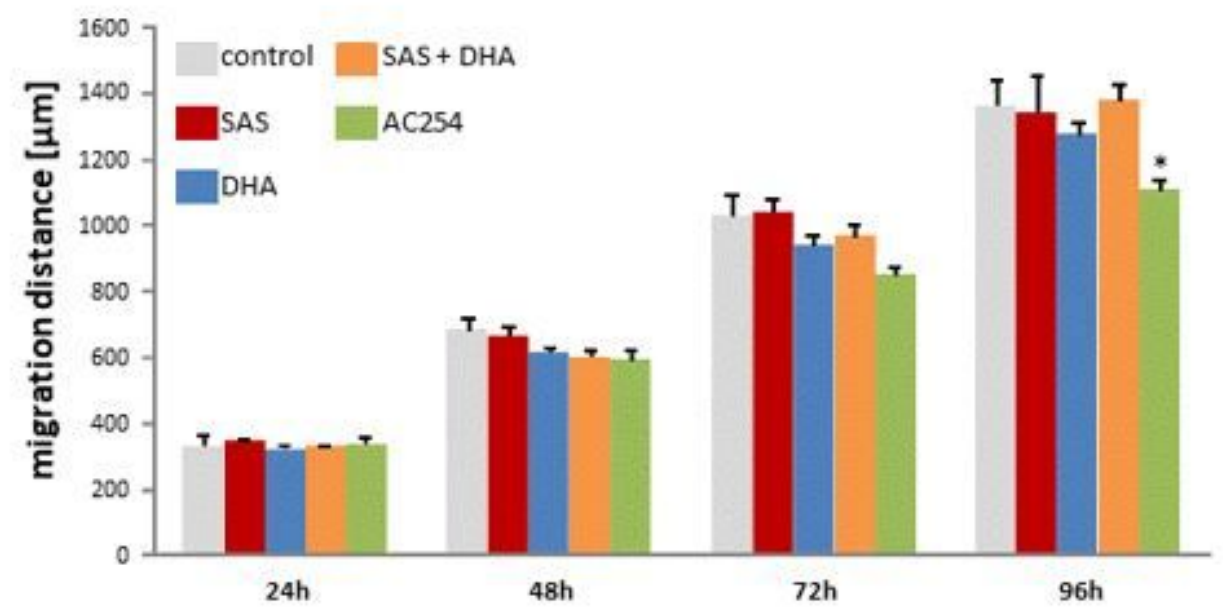

Figure 10 
Impact of the substances on cell migration A, U87 were treated with $5 \mu \mathrm{M}$ and observed for 4 days. Scale bar: $1000 \mu \mathrm{m}$. B, Migration distance was measured.
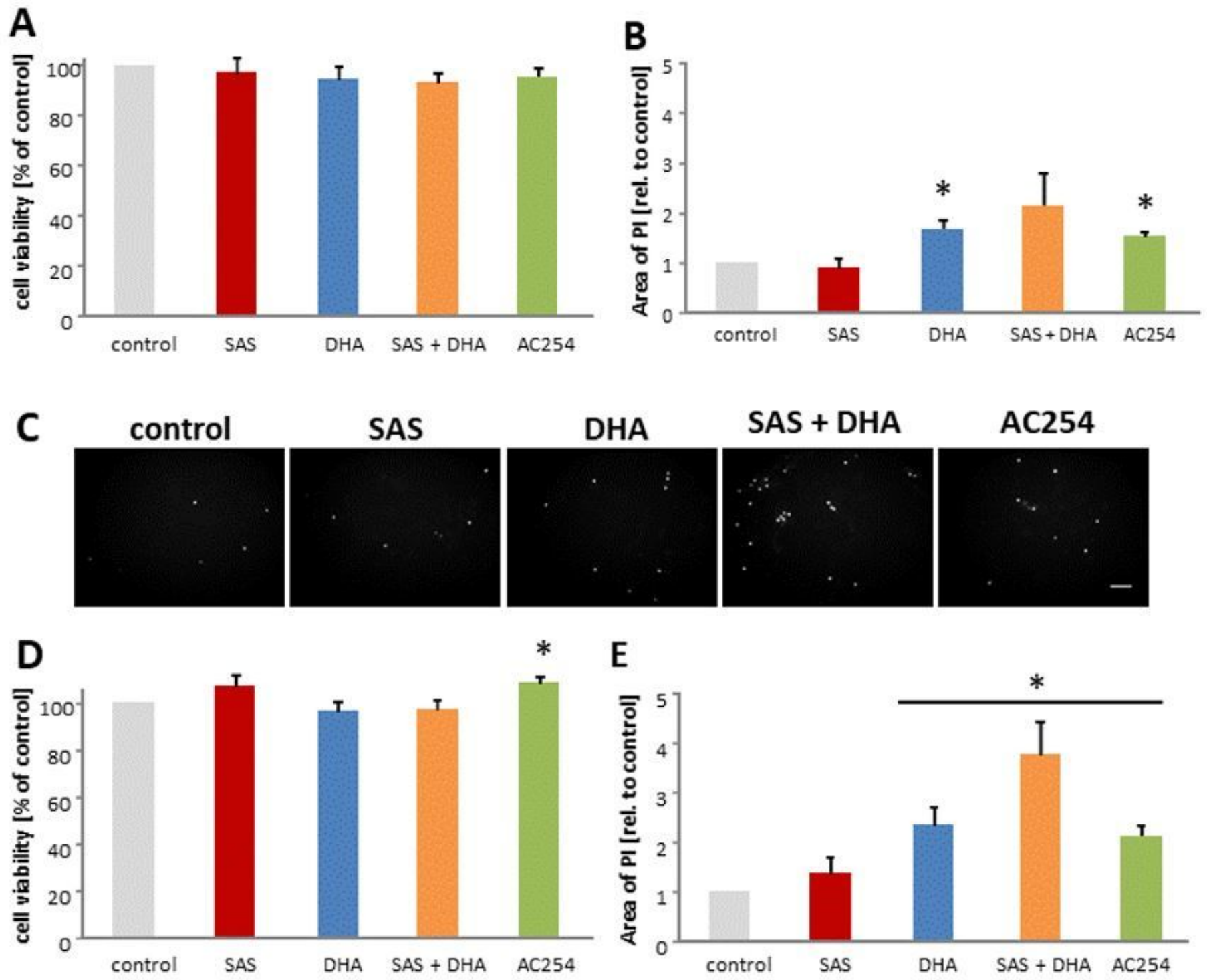

\section{Figure 11}

Neurotoxicity an gliomatoxicity profiling A, D Cells were treated with $1 \mu \mathrm{M}(\mathrm{A})$ and $5 \mu \mathrm{M}(\mathrm{D})$ of the compounds. Cell viability assay was performed after $72 \mathrm{~h}$. Statistical significance was tested with unpaired two-sided t-test vs. control ( $n \geq 6$; *, $p \leq 0.05)$. B, C, E Cells were treated with $1 \mu \mathrm{M}(\mathrm{B})$ and $5 \mu \mathrm{M}$ $(\mathrm{C}, \mathrm{E})$ of the compounds. Cells were stained for propidium iodid $(\mathrm{PI})$. Representative pictures were taken (C), scale bar: $200 \mu \mathrm{m}$. Images were quantified for area of PI fluorescence (B, E). Statistical significance was tested with unpaired two-sided t-test vs. control $(n \geq 5 ; *, p \leq 0.05)$.

\section{Supplementary Files}

This is a list of supplementary files associated with this preprint. Click to download. 
- SupportingInformation06012021.pdf 